\title{
Growth and phosphorus uptake by the toxic dinoflagellate Alexandrium catenella (dinophyceae) in response to phosphate limitation
}

\author{
Cécile Jauzein ${ }^{1}$, Claire Labry ${ }^{2}$, Agnès Youenou ${ }^{2}$, Julien Quéré ${ }^{2}$, Daniel Delmas ${ }^{2}$, Yves Collos $^{3,}{ }^{*}$ \\ ${ }^{1}$ IFREMER, Laboratoire LER-LR, BP 171, 34203 Sète Cedex, France \\ ${ }^{2}$ IFREMER/Centre de Brest, Laboratoire DYNECO-Pelagos, BP 70, 29280 Plouzané, France \\ ${ }^{3}$ Université Montpellier 2, CNRS, Ifremer, IRD, Laboratoire Ecosystèmes Lagunaires (UMR 5119), Cc 093,34095 \\ Montpellier Cedex 5, France \\ *: Corresponding author : Y. Collos, email address : yves.collos@univ-montp2.fr
}

\begin{abstract}
:
Alexandrium catenella (Whedon et Kof.) Balech has exhibited seasonal recurrent blooms in the Thau lagoon (South of France) since first reported in 1995. Its appearance followed a strong decrease $(90 \%)$ in phosphate $\left(\mathrm{PO}_{4}{ }^{3-}\right)$ concentrations in this environment over the $1970-1995$ period. To determine if this dinoflagellate species has a competitive advantage in $\mathrm{PO}_{4}{ }^{3-}$-limited conditions in terms of nutrient acquisition, semicontinuous cultures were carried out to characterize phosphorus $(P)$ uptake by $A$. catenella cells along a P-limitation gradient using different dilution rates (DRs). Use of both inorganic and organic $\mathrm{P}$ was investigated from measurements of ${ }^{33} \mathrm{PO}_{4}{ }^{3-}$ uptake and alkaline phosphatase activity (APA), respectively. $P$ status was estimated from cellular $\mathrm{P}$ and carbon contents $\left(Q_{P}\right.$ and $\left.Q_{C}\right)$. Shifts in trends of $Q_{P} / Q_{C}$ and $Q_{P}$ per cell $\left(Q_{P \cdot c e l l-1}\right)$ along the DR gradient allowed the definition of successive P-stress thresholds for $A$. catenella cells. The maximal uptake rate of ${ }^{33} \mathrm{PO}_{4}{ }^{3-}$ increased strongly with the decrease in DR and the decrease in $Q_{\mathrm{P}} / Q_{\mathrm{C}}$, displaying physiological acclimations to $\mathrm{PO}_{4}{ }^{3-}$ limitation. Concerning maximal APA per cell, the observation of an all-or-nothing pattern along the dilution gradient suggests that synthesis of AP was induced and maximized at the cellular scale as soon as $\mathrm{PO}_{4}{ }^{3-}$ limitation set in. APA variations revealed that the synthesis of AP was repressed over a $\mathrm{PO}_{4}{ }^{3-}$ threshold between 0.4 and $1 \mu \mathrm{M}$. As lower $\mathrm{PO}_{4}{ }^{3-}$ concentrations are regularly observed during $A$. catenella blooms in Thau lagoon, a significant portion of $P$ uptake by $A$. catenella cells in the field may come from organic compounds.
\end{abstract}

Keywords: Alexandrium catenella; alkaline phosphatase; limitation; phosphorus; semicontinuous cultures 


\section{Abbreviations:}

APA

alkaline phosphatase activity DOP

dissolved organic phosphorus MFP

methylfluorescein-phosphate MUF-P

methyl-umbelliferyl phosphate POC

particulate organic carbon POP

particulate organic phosphorus 


\section{INTRODUCTION}

Phosphorus $(\mathrm{P})$ deficiency in marine systems has been reported for several open-ocean areas and coastal waters (Vidal et al. 2003, Labry et al. 2005, Thingstad et al. 2005) and may lead to growth limitation of both phytoplankton and heterotrophic bacteria communities (Thingstad et al. 1998). In such environments, a significant fraction of the total dissolved phosphorus pool (TDP) often corresponds to dissolved organic phosphorus (DOP) (Karl and Yanagi 1997, Karl and Björkman 2002, Suzumura and Ingall 2004), making the enzymatic remineralization of organic $\mathrm{P}$ compounds a key process in population competition.

In the Thau lagoon (South of France), the role of organic P compounds may have become more critical for organisms' nutrition as a strong decrease in phosphate $\left(\mathrm{PO}_{4}{ }^{3-}\right)$ concentrations has been observed over the last four decades, with values in summer and winter dropping from $10 \mu \mathrm{M}$ to $1 \mu \mathrm{M}$ and from $3 \mu \mathrm{M}$ to undetectable $(<0.03 \mu \mathrm{M})$, respectively (Collos et al. 2009). This oligotrophication principally occurred during the 19701995 period, as a consequence of effective implementation of waste water collection and treatment facilities (La Jeunesse and Elliott 2004). The year 1995 coincided with the first report of the toxic dinoflagellate Alexandrium catenella (Whedon et Kofoid) Balech in Thau lagoon waters, followed by a first Paralytic Shellfish Poisoning (PSP) toxic event in 1998 (Lilly et al. 2002). Ever since 1998 seasonal recurrent blooms of A. catenella have been observed, suggesting the oligotrophication has created a niche where A. catenella may grow and become periodically dominant.

In the present study, P-uptake characteristics of A. catenella cells were analyzed to determine if this species manifests a competitive advantage for $\mathrm{P}$-acquisition in $\mathrm{PO}_{4}{ }^{3-}$ limited conditions. Alexandrium spp., and in particular A. catenella, are known to produce alkaline phosphatase (Oh et al. 2002, Ou et al. 2006) when $\mathrm{PO}_{4}{ }^{3-}$ deficient. This enzyme hydrolyzes ester bonds between $\mathrm{PO}_{4}{ }^{3-}$ and dissolved organic compounds, making $\mathrm{PO}_{4}{ }^{3-}$ available for 
cellular assimilation (Perry 1972). As the DOP resource might be critical for cellular growth in Thau lagoon waters, both the use of inorganic and organic P-sources were examined by carrying out $\mathrm{PO}_{4}{ }^{3-}$-uptake and alkaline phosphatase activity (APA) measurements along a Plimitation gradient.

\section{MATERIALS AND METHODS}

Experimental design. Two strains of A. catenella were tested: TL01 and ACT03, isolated respectively in 1998 and 2003 in Thau lagoon, France. Nonaxenic cultures were maintained on ESAW artificial seawater (Andersen et al. 2005) at $20 \pm 1{ }^{\circ} \mathrm{C}$ and were illuminated with $100 \mu \mathrm{mol} \cdot \mathrm{photons} \cdot \mathrm{m}^{-2} \cdot \mathrm{s}^{-1}$ under a $12 \mathrm{~h}$ light $: 12 \mathrm{~h}$ dark cycle.

For each strain, one stock culture was used to inoculate 14 3L-flasks using ESAW medium with $\mathrm{PO}_{4}{ }^{3-}$ concentration limited to ESAW/4 (N:P = 98). These cultures were run under batch conditions until $\mathrm{PO}_{4}{ }^{3-}$ concentrations were reduced to less than $0.2 \mu \mathrm{M}$. Cultures were gently mixed prior to the regular monitoring of $\mathrm{PO}_{4}{ }^{3-}$ concentrations. The cultures were then maintained semi-continuously renewing a part of the medium every $24 \mathrm{~h}$. The fresh medium used for dilutions was based on ESAW composition with modified $\mathrm{PO}_{4}{ }^{3-}$ and nitrate $\left(\mathrm{NO}_{3}{ }^{-}\right)$concentrations, corresponding to $9.1 \mu \mathrm{M}$ and $882.5 \mu \mathrm{M}$ respectively $(\mathrm{N}: \mathrm{P}=98)$. Seven dilution rates $(\mathrm{DRs})$ were assayed $\left(0.05,0.10,0.15,0.20,0.30,0.40,0.50 \mathrm{~d}^{-1}\right)$ with replicated cultures. After each renewal, the withdrawn water samples were used to measure $\mathrm{PO}_{4}{ }^{3-}, \mathrm{NO}_{3}{ }^{-}$ + nitrite $\left(\mathrm{NO}_{2}{ }^{-}\right)$, and $A$. catenella cell concentrations.

After nine days of semi-continuous conditions, equilibrium was presumed as changes in nutrient concentrations over $3 \mathrm{~d}$ were $<10 \%$ in all $3 \mathrm{~L}$-cultures and cell density varied by less than $20 \%$, except for one DR under which density variations were $<30 \%$. Cultures were continuously subjected to daily dilutions until the end of the experiment. On days 1,2 and 3 after equilibrium, additional measurements of maximal $\mathrm{PO}_{4}{ }^{3-}$-uptake rate, maximal alkaline 
phosphatase activity (APA) and cellular composition parameters were performed for each DR. These measurements were done using withdrawn water samples from both replicated cultures mixed together in order to increase available sampling volume making it possible to perform duplicates. On following days 4, 5 and 6, the whole of a 3L-culture was used to do kinetics measurements of $\mathrm{PO}_{4}{ }^{3-}$ uptake rate and APA. From the sacrifice of one culture per day, three different DR conditions were tested for each strain, $0.15 \mathrm{~d}^{-1}, 0.2 \mathrm{~d}^{-1}, 0.3 \mathrm{~d}^{-1}$ for TL01 and $0.1 \mathrm{~d}^{-1}, 0.15 \mathrm{~d}^{-1}, 0.2 \mathrm{~d}^{-1}$ for ACT03.

\section{Chemical measurements and cell counts. Samples for $\mathrm{PO}_{4}{ }^{3-}$ and $\mathrm{NO}_{3}{ }^{-}+\mathrm{NO}_{2}{ }^{-}$}

determination were carefully filtered through glass fiber filters (Whatman GF/F, Maidstone, U.K.) with a syringe filtration system. Filtrates were used for nutrient concentration measurements on a Bran+Luebbe/Seal (Norderstedt, Germany) AutoAnalyzer 3 following Aminot and Kérouel (2007).

For measurements of particulate phosphorus and carbon, water samples were filtered through pre-combusted $\left(12 \mathrm{~h}\right.$ at $\left.400^{\circ} \mathrm{C}\right) 25 \mathrm{~mm}$ Whatman GF/D filters which were then maintained at $-20^{\circ} \mathrm{C}$ until analysis. Particulate organic phosphorus (POP) was measured according to Solórzano and Sharp (1980). Particulate organic carbon (POC) was determined based on the method of Aminot and Kérouel (2004) using a VarioEL III carbon-nitrogen elemental analyzer (Elementar, Hanau, Germany). POP and POC standardized by A. catenella cell densities were used to represent the $\mathrm{P}$-status $(\mathrm{Qp})$ and $\mathrm{C}$ content $\left(\mathrm{Q}_{\mathrm{C}}\right)$, respectively. Cell concentrations were estimated from water samples fixed with formaldehyde (final concentration of 5\%) using a haemocytometer. Cell counts were performed in duplicate, counting more than 400 cells per sample, and in triplicate otherwise.

$$
\mathrm{PO}_{4}{ }^{3-} \text {-uptake rate. Rates of } \mathrm{PO}_{4}{ }^{3-} \text { uptake were measured using the }{ }^{33} \mathrm{PO}_{4}{ }^{3-}
$$
incorporation technique. On days 1, 2 and 3 after equilibrium, maximal uptake rates $\left(\mathrm{V}_{\max }\right)$ were estimated for each DR on water samples varying from $150 \mathrm{~mL}$ (lowest DR) to $1000 \mathrm{~mL}$ 
127 (highest DR) in polycarbonate bottles. After adjusting the $\mathrm{PO}_{4}{ }^{3-}$ concentration of water 128 samples to $6.4 \mu \mathrm{M}$, incubations started with the addition of $20 \mu \mathrm{Ci}^{33} \mathrm{PO}_{4}{ }^{3-}$ and were ended by the addition of formaldehyde (4\% final concentration). Different incubation times ranging from 5 min to $6 \mathrm{~h}$ were used and $\mathrm{PO}_{4}{ }^{3-}$ uptake rates were calculated from the linear part of the ${ }^{33} \mathrm{P}$ incorporation time series. For kinetics experiments on days 4, 5 and 6 , similar incubations were performed by adding graded $\mathrm{PO}_{4}{ }^{3-}$ concentrations $(0.05,0.1,0.2,0.4,0.8,1.6,3.2$ and $\left.6.4 \mu \mathrm{M} \mathrm{KH}_{2} \mathrm{PO}_{4}\right)$ and $16 \mu \mathrm{Ci}^{33} \mathrm{PO}_{4}{ }^{3-}$ to $250 \mathrm{~mL}$-subsamples originating from the same $3 \mathrm{~L}$ flask. At the end of incubations, samples were filtered through $8 \mu \mathrm{m} 25 \mathrm{~mm}$ cellulose ester (SCWP02500) Millipore (Billerica, Mass., U.S.A.) filters. Then, filters were rinsed twice with $5 \mathrm{~mL}$ of $0.2 \mu \mathrm{m}$ filtered AW water and stored with $4 \mathrm{~mL}$ of scintillation cocktail until they were counted with a liquid scintillation counter (Wallac Model 1414, EG/G Istruments / Perkin-Elmer, Turku, Finland).

Alkaline phosphatase activity. APA measurements were performed in duplicate on subsamples obtained with and without pre-filtration of the water-samples through 0.2 or 10 $\mu \mathrm{m}$ polycarbonate filters. From the fractionated APA measurements, APA linked to $A$. catenella cells surface was determined by subtracting the APA in the $<10 \mu \mathrm{m}$ fraction from the total APA and APA obtained from the $0.2 \mu \mathrm{m}$ filtrate was regarded as soluble APA. Fractionated APA was assayed by using the fluorogenic substrate methyl-umbelliferyl phosphate (MUF-P) (Hoppe 1983, Ammerman 1993). On days 1, 2 and 3 after equilibrium, a MUF-P final concentration of $250 \mu \mathrm{M}$ was added to $2 \mathrm{~mL}$-water samples to determine maximal hydrolysis rates along the DR gradient. For kinetics experiments on days 4, 5 and 6, ten MUF-P final concentrations ranging from 0.5 to $250 \mu \mathrm{M}$ were used. Incubations were carried out in the dark at $20^{\circ} \mathrm{C}$ and were ended by formaldehyde addition, with final concentration of $4 \%$, and by freezing the samples at $-20^{\circ} \mathrm{C}$. Incubations were stopped when APA variations with time were still linear, avoiding hydrolysis of the main portion of 
available MUF-P. For estimations of maximal activities along the DR gradient, incubations were 30 - 60 min, increasing with increasing DR; for kinetics experiments, incubations were 15 min when substrate concentration was lower than $2 \mu \mathrm{M}$, otherwise $30 \mathrm{~min}$. The concentrations of the dephosphorylated fluorescent product 4-methyl-umbelliferone (MUF) at the end of incubations were estimated from fluorescence (365 nm excitation and $460 \mathrm{~nm}$ emission) measured by flow injection analysis (Delmas et al. 1994, Labry et al. 2005) with a buffered solution of borate $(0.1 \mathrm{M}, \mathrm{pH} 10.5)$ as the carrier fluid. To convert units of MUF fluorescence into concentration values, a calibration curve $\left(\mathrm{R}^{2}>0.999\right)$ was performed with standard solutions of MUF in the range $0.02-20 \mu \mathrm{M}$.

Data treatments - Analysis along the DR gradient. Each strain had 2 replicate cultures at each DR. For each replicate the $\mathrm{PO}_{4}{ }^{3-}$ and cell concentrations obtained on days 1,2 and 3 after equilibrium were averaged and then used to estimate the mean and standard deviation for each strain TL01 $(n=2)$ and ACT03 (n=2). Two tailed t-tests were used to test strain differences in $\mathrm{PO}_{4}{ }^{3-}$ concentrations and significance of cell concentration trends along the DR gradient. Measurements of POP, POC, ${ }^{33} \mathrm{P}$-uptake rate and APA were undertaken on water samples of both replicated cultures mixed together, therefore these data are presented as an average of days 1, 2 and 3 values along the DR gradient. They were used for linear regression and curve fitting. All statistical analyses were undertaken using the Prism 4.0b software (Graph Pad Software, San Diego, CA., U.S.A.).

Data treatments - Kinetic and quota parameters. From data collected on days 4, 5 and 6 after equilibrium, maximal uptake rates $\left(\mathrm{V}_{\max }\right)$ and half-saturation constants $\left(\mathrm{K}_{\mathrm{S}}\right)$ of $\mathrm{PO}_{4}{ }^{3-}-$ uptake rate and APA were determined using the Michaelis-Menten relation:

$$
\mathrm{V}=\mathrm{V}_{\max } \cdot[\mathrm{S}] /\left(\mathrm{K}_{\mathrm{S}}+[\mathrm{S}]\right)
$$

where the uptake rate $\mathrm{V}\left(\right.$ in $\mathrm{h}^{-1}$ ) is function of the maximal uptake rate $\mathrm{V}_{\max }\left(\right.$ in $\mathrm{h}^{-1}$ ), the halfsaturation constant $\mathrm{K}_{\mathrm{S}}$ (in $\mu \mathrm{M}$ ) and the substrate concentration [S] (in $\mu \mathrm{M}$ ). 
For APA, half of the data series did not show a clear intermediate saturation plateau, but a single Michaelis-Menten model did not correctly represent the data either, with a net underestimation of enzyme activity at high substrate concentrations. This was probably due to the high dependence of the kinetic parameters values upon the range of substrate concentration considered (McComb et al. 1979) rather than to a potential multi-enzymatic system such as the one described for the coccolithophorid Emiliana huxleyi (Riegman et al. 2000, Dyhrman and Palenik 2003). Taking into account the potential patchiness of nutrient concentrations at the cellular scale (Shanks and Trent 1979), we choose to consider biphasic patterns to avoid distorted estimations of kinetic parameters; one equation was used to obtain an estimation of the enzyme affinity $\left(\mathrm{K}_{\mathrm{S}}\right)$ in the range of low substrate concentrations and the other to estimate the enzyme capacity $\left(\mathrm{V}_{\max }\right)$ using data at high substrate concentrations. This approach is supported by the consistency between parameters values obtained from uniphasic and biphasic models (see results).

Quota measurements and theoretical growth rates estimated along the DR gradient were used to test the Droop relation (Droop 1968):

$$
\mu=\mu_{\max } \cdot\left(1-q_{o} / Q\right)
$$

where $\mu\left(\right.$ in $\left.^{-1}\right)$ is the theoretical growth rate, $\mathrm{Q}$ is the quota (in $\mathrm{pg} \cdot \mathrm{pgC}^{-1}$ or $\mathrm{pg} \cdot \mathrm{cell}^{-1}$ ), $\mathrm{q}_{\mathrm{o}}$ is the theoretical minimum quota (in pg.pgC ${ }^{-1}$ or $\mathrm{pg} \cdot \mathrm{cell}^{-1}$ ) and $\mu_{\max }$ is the theoretical maximum growth rate at infinite $\mathrm{Q}\left(\right.$ in $\left.\mathrm{d}^{-1}\right)$.

Values of $\mu$ (in $\mathrm{d}^{-1}$ ) were calculated from the dilution rate DR $\left(\mathrm{d}^{-1}\right)$ according to Tilman and Kilham (1976):

$$
\mu=-\ln (1-\mathrm{DR})
$$

\section{RESULTS}



phosphate concentrations with decreasing DR was observed between 0.5 and $0.3 \mathrm{~d}^{-1}$ and reached values lower than $0.3 \mu \mathrm{M}$ for cultures diluted at $0.2 \mathrm{~d}^{-1}$ and less (Fig. 1a). Along this decrease, phosphate concentrations were significantly lower (two tailed t test, $\mathrm{p}<0.002$ ) in the TL01 cultures compared to the ACT03 cultures but only at DR $=0.4 \mathrm{~d}^{-1}$.

Along the dilution gradient cell concentrations were maximal at $\mathrm{DR}=0.2$ and $0.15 \mathrm{~d}^{-1}$ for TL01 and ACT03 cultures, respectively (Fig. 1b and 1c). The maximum was particularly evident for TL01 with a significant decrease (two tailed t test, $\mathrm{p}<0.01$ ) of $47 \%$ between the maximal value and the density measured at the lowest DR $\left(0.05 \mathrm{~d}^{-1}\right)$. For both strains, the proportion of single cells decreased with increasing DR. But the DR associated with the maximal cell concentration defined a threshold in chain formation: it corresponds to a shift where the increase in the percentage of two cell chains with DR was replaced by an increase in the percentage of four cell chains (Fig. $1 \mathrm{~b}$ and $1 \mathrm{c}$ ).

\section{Cellular composition parameters. When expressed on per cell basis, overall Qp} variation observed along the DR gradient followed the pattern of $\mathrm{PO}_{4}{ }^{3-}$ concentrations (Fig. 2a). For DR $\leq 0.2 \mathrm{~d}^{-1}$, no trend was visible in the relationship between cellular $\mathrm{Qp}(\mathrm{Qp} / \mathrm{cell})$ and $\mathrm{DR}$, as $\mathrm{Qp}_{\text {/cell }}$ values were constrained at low levels surrounding a mean value of $24.8 \pm 2.6$ pgP.cell ${ }^{-1}$ compiled from both strains measurements, with a minimum value $(\mathrm{Qp} /$ cell-min $)$ of $20.3 \mathrm{pgP} \cdot \mathrm{cell}^{-1}$. At higher DRs, a net increase in $\mathrm{Qp}$ /cell with the DR was apparent only for the ACT03 strain with a Qp value $(\mathrm{Qp} /$ cell-max $)$ of $61.1 \mathrm{pgP} \cdot$ cell $^{-1}$ obtained at $\mathrm{DR}=0.5 \mathrm{~d}^{-1}$. For TL01, Qp $/$ cell values appeared to be higher in the range of DR $0.3-0.5 \mathrm{~d}^{-1}$, however they only reached $33.1 \mathrm{pgP} \cdot \mathrm{cell}^{-1}$ at the highest DR.

Trends in $\mathrm{P}$ quota values normalized to cellular carbon $\left(\mathrm{Qp} / \mathrm{Q}_{\mathrm{C}}\right)$ were different from the $\mathrm{Qp}_{\text {/cell }}$ variations (Fig. 2b). From a minimal value $\left(\mathrm{Qp} / \mathrm{Q}_{\mathrm{C}-\min }=0.010 \mathrm{pgP} \cdot \mathrm{pgC}^{-1}\right)$ obtained at the minimal DR, Qp/Q increased regularly with increasing DR and reached a maximum 
226 plateau at an intermediate DR: $0.4 \mathrm{~d}^{-1}$ for TL01 and $0.3 \mathrm{~d}^{-1}$ for ACT03. For both strains this

227 plateau was characterized by a mean value of $0.021 \pm 0.001 \mathrm{pgP} \cdot \mathrm{pgC}^{-1}$, slightly lower than the

228 Redfield ratio $\left(0.024 \mathrm{pgP} \cdot \mathrm{pgC}^{-1}\right)$. This pattern of $\mathrm{Qp} / \mathrm{Q}_{\mathrm{C}}$ variation with $\mathrm{DR}$ was particularly

229 visible for ACT03, for which a linear increase $\left(\mathrm{R}^{2}=0.95, \mathrm{p}<0.005\right)$ was observed between $230 \quad 0.05 \mathrm{~d}^{-1}$ and $0.3 \mathrm{~d}^{-1}$.

As discussed below, only data obtained at DRs ranging from $0.2 \mathrm{~d}^{-1}$ to $0.5 \mathrm{~d}^{-1}$ for TL01 and $0.15 \mathrm{~d}^{-1}$ to $0.5 \mathrm{~d}^{-1}$ for ACT03 may be compatible with Droop's theory. Data from both strains were fitted to Droop's model (data not shown) to estimate the theoretical minimum quota $\left(\mathrm{q}_{\mathrm{o}}\right)$ associated with a zero growth rate. From Qp values expressed on a per cell basis, a value close to the $\mathrm{Qp}_{\text {/cell-min }}$ measurement was obtained, $\mathrm{q}_{\mathrm{o}}=16.4 \mathrm{pgP} \cdot \mathrm{cell}^{-1}\left(\mathrm{r}^{2}=0.54\right)$. From

Qp estimations per cellular C unit, a qo value $\left(0.010 \mathrm{pgP} \cdot \mathrm{pgC}^{-1}\right)$ equal to the $\mathrm{Qp} / \mathrm{Q}_{\mathrm{C}-\mathrm{min}}$ measurement was calculated $\left(\mathrm{r}^{2}=0.67\right)$.

${ }^{33} P$-uptake rates. Data from DR $=0.5 \mathrm{~d}^{-1}$ for ACT03 strain were not included as they were clearly inconsistent with the rest of the data. Along the DR gradient, $\mathrm{Vp} \mathrm{p}_{\max }$ showed a maximum at the lowest DR, corresponding to $1.9 \mathrm{fmolP} \cdot \mathrm{cell}^{-1} \cdot \mathrm{min}^{-1}$ and $1.4 \mathrm{fmolP} \cdot \mathrm{cell}^{-1} \cdot \mathrm{min}^{-1}$ $\left(0.129 \mathrm{~h}^{-1}\right.$ and $0.097 \mathrm{~h}^{-1}$ after division by Qp/cell $)$ for TL01 and ACT03 respectively (Fig. 3a). A regular decrease of $V p_{\max }$ with the DR was observed as DR increased from $0.05 \mathrm{~d}^{-1}$ to $0.3 \mathrm{~d}^{-}$ ${ }^{1}$ and a mean value of $\mathrm{Vp}$ max of $0.2 \pm 0.1 \mathrm{fmolP} \cdot \mathrm{cell}^{-1} \cdot \mathrm{min}^{-1}\left(0.014 \pm 0.009 \mathrm{~h}^{-1}\right)$ was obtained for $\mathrm{DR} \geq 0.3 \mathrm{~d}^{-1}$, compiling data of both strains.

Considering variation of $\mathrm{Vp}_{\max }$ as a function of extracellular $\mathrm{PO}_{4}{ }^{3-}$ concentrations (Fig. $3 b): V p_{\max }$ higher than $0.42 \mathrm{fmolP} \cdot \mathrm{cell}^{-1} \cdot \mathrm{min}^{-1}\left(0.039 \mathrm{~h}^{-1}\right)$ were associated with $\mathrm{PO}_{4}{ }^{3-}$ concentrations lower than $0.34 \mu \mathrm{M}$. Above this threshold, $\mathrm{Vp} \mathrm{p}_{\max }$ remained near $0.21 \pm 0.11$

$248 \mathrm{fmolP} \cdot \mathrm{cell}^{-1} \cdot \mathrm{min}^{-1}$, corresponding to $0.011 \pm 0.007 \mathrm{~h}^{-1}$. No relationship was found between $249 \mathrm{Vp} \mathrm{p}_{\max }$ and $\mathrm{Qp} /$ cell, but an exponential decrease was observed representing $\mathrm{Vp} \mathrm{p}_{\max }$ as a function 250 of Qp/QC $\left(r^{2}=0.68\right)$ (Fig. 3c). 
From kinetics experiments testing three DR conditions for each strain, variations of

$252 \mathrm{PO}_{4}{ }^{3-}$ uptake rates as a function of concentrations followed the Michaelis-Menten model with

$253 \quad \mathrm{r}^{2} \geq 0.79$. The maximal P-uptake rate $\mathrm{V}_{\max (\mathrm{P})}$ showed a net decrease as the DR increased

254 (Table 1), in accordance with previous trends observed in $\mathrm{PO}_{4}{ }^{3-}$ uptake rate data (Fig. 3a).

Associated $\mathrm{K}_{\mathrm{S}(\mathrm{P})}$ values ranged between $0.01 \mu \mathrm{M}$ and $1.17 \mu \mathrm{M}$ for TL01 and between 0.03 $\mu \mathrm{M}$ and $0.14 \mu \mathrm{M}$ for ACT03 (Table 1).

APA measurements. The main part of the APA measured in the total fraction was cellbound. The dissolved APA $(<0.2 \mu \mathrm{m})$ represented less than $13 \%$ of the total APA for all measurements, while for most of the data $(77 \%)$ it reached less than $5 \%$ of the total fraction (data not shown). Considering the variation of maximal APA per cell as a function of DR, values showed an all-or-nothing pattern (Fig. 4a). Significant APA measurements were obtained for DR $\leq 0.3 \mathrm{~d}^{-1}$ for TL01 and $0.2 \mathrm{~d}^{-1}$ for ACT03, with no particular trend observed as the DR decreased. In this range, maximal normalized APA varied around respective means values of $13.4 \pm 3.6 \mathrm{fmolP} \cdot \mathrm{cell}{ }^{-1} \cdot \mathrm{min}^{-1}$ and $10.0 \pm 3.2 \mathrm{fmolP} \cdot \mathrm{cell}^{-1} \cdot \mathrm{min}^{-1}$ for TL01 and ACT03, respectively.

Expressed as a function of $\mathrm{PO}_{4}{ }^{3-}$ concentrations (Fig. 4b), values of maximal APA per cell showed a pattern clearly defined by a threshold value between $0.4 \mu \mathrm{M}$ and $1.0 \mu \mathrm{M}$ of $\mathrm{PO}_{4}{ }^{3-}$. A similar pattern was observed considering maximal APA per cell as a function of Qp/Q $\mathrm{Q}_{\mathrm{C}}\left(\right.$ Fig. 4c) and highlighted a strict threshold at $\mathrm{Qp} / \mathrm{Q}_{\mathrm{C}}=0.016 \mathrm{pgP} \cdot \mathrm{pgC}^{-1}(\mathrm{C}: \mathrm{P}$ ratio of 161) which separated large APA values from negligible ones. The relation observed between maximal APA and Qp/cell values was not so clear-cut, but large APA values were obtained for $\mathrm{Qp}_{/ \text {cell }}<42.1 \mathrm{pgP} \cdot \operatorname{cell}^{-1}$ (Fig. 4d).

Along the MUF-P gradient of $0.5-250 \mu \mathrm{M}$, three series of specific APA measurements were done for each strain corresponding to three different DRs. The use of a single Michaelis-Menten equation did not allow a convergence of the hyperbolic regression 
analysis with confidence intervals of $95 \%$ in all cases. For three of the six kinetic experiments, the use of a single equation did not lead to a random dispersion of normalized residuals along the substrate gradient, with a trend suggesting that the model tends to overestimate activities between 3.9 and $62.5 \mu \mathrm{M}$ of MUF-P and underestimate them at higher substrate concentrations. To avoid distorted estimations of kinetic parameters, biphasic patterns described by two Michaelis-Menten equations were used to model these data, with a transition between both phases in the range $31.3-62.5 \mu \mathrm{M}$ of MUF-P (Fig. 5). For biphasic models, $\mathrm{K}_{\mathrm{S}}$ values of Phase I estimate AP affinity of $A$. catenella cells and $\mathrm{V}_{\max }$ values of Phase II estimate enzyme efficiency under high substrate concentrations. Comparing these parameters values with the $\mathrm{K}_{\mathrm{S}}$ and $\mathrm{V}_{\max }$ values of uniphasic models (Table 1), no trend was clear in APA $K_{S}$ and $V_{\max }$ values with DR.

\section{DISCUSSION}

P-limitation conditions. Phosphate pulses were almost entirely consumed after $24 \mathrm{~h}$ in the cultures diluted at $\mathrm{DR} \leq 0.2 \mathrm{~d}^{-1}$, suggesting that the DR gradient from $0.05-0.5 \mathrm{~d}^{-1}$ imposed a severe P-limitation on A. catenella cells maintained at low DRs. The rate of chain formation reflected the graded phosphate conditions, probably due to a more general relationship between chain formation and growth rate. Considering total cell concentrations, a critical dilution rate can be defined for each strain from the maximum observed cell density $\left(D R_{3}\right.$ on Figure 6). Maximal values at intermediate DRs were unexpected as cell concentrations often decrease linearly with DR, matching Droop's model (1968). Divergences from this theoretical trend may be observed under low DRs where cultures may reach particular steady states well described by Sciandra and Ramani (1994). According to these authors, decreasing cell density at low DRs $\left(\mathrm{DR} \leq 0.3 \mathrm{~d}^{-1}\right)$ may be explained by additional controlling factors, such as competition with bacteria or negative effects due to accumulation 
of excreted products. Shafik et al. (1997) and Le Floc'h et al. (2002) also reported cellular densities lower than the ones supported by Droop's model at low DRs (DR $\left.\leq 0.11 \mathrm{~d}^{-1}\right)$. At the cellular scale, the graded P-stress conditions led to a decrease in Qp per cell $\left(\mathrm{Qp}_{\text {/cell }}\right)$ followed by a decrease in Qp per C unit (Qp/QC) as the DR decreased (Fig. 6). These trends were particularly visible for ACT03. The uncoupling observed at highest DRs between $\mathrm{Qp}_{/ \text {cell }}$ and $\mathrm{Qp} / \mathrm{Q}_{\mathrm{C}}$ variations defines a first $\mathrm{P}$-stress range where conditions are still $\mathrm{P}$ sufficient for cell metabolism but the cell size decreases when the P-stress increases. The start of a decrease in $\mathrm{Qp} / \mathrm{Q}_{\mathrm{C}}$ when the $\mathrm{DR}$ decreases $\left(D R_{1}\right.$ on Figure 6) indicates the threshold between P-sufficient conditions and P-limitation. P-starvation conditions are then encountered when $\mathrm{Qp}_{\text {/cell }}$ reaches the minimum plateau $\left(D R_{2}\right.$ on Figure 6). Below this P-starvation threshold $\left(D R_{2}\right)$, Qp could not act as a buffer against external $\mathrm{PO}_{4}{ }^{3-}$ depletion. Consequently, when $\mathrm{PO}_{4}{ }^{3-}$ from the daily pulse was exhausted, cells could not use the internal $\mathrm{P}$ pool to support their growth. Under these P-starvation conditions, cell size probably increased with Pstress as $\mathrm{Qp}_{\text {/cell }}$ was maintained when $\mathrm{Qp} / \mathrm{Q}_{\mathrm{C}}$ decreased with decreasing DR. This could explain the observed decrease in cell density at lowest DRs by a lag in cell division leading to growth rates that are lower than the ones predicted by Droop's theory.

Contrary to our results, Matsuda et al. (2006) observed a maximal cell density and a minimal Qp/cell at the lowest DR $\left(0.05 \mathrm{~d}^{-1}\right)$ in semi-continuous experiments performed with axenic cultures of A. catenella along a P-limitation DR gradient of $0.05-0.35 \mathrm{~d}^{-1}$. Our non axenic experiments may have imposed additional controlling factors for A. catenella growth at low DRs such as: (i) competition with bacteria, resulting in more severe P-limitation conditions for algal cells, or (ii) cell density effects as the maximal cell concentration in the present study is seven fold higher than the one reported in Matsuda et al. (2006). The discrepancies noted along similar DR gradients also suggest that the French strains of $A$. 
catenella may be more sensitive to P-stress than the Japanese strain TNY7 used by Matsuda et al. (2006).

P-storage capacities. The range of Qp values gives an indication of potential $\mathrm{P}$-storage capacities of algal cells from the evaluation of the "luxury coefficient" defined by Droop (1974) as the ratio between the maximum and the minimum quotas, determined in non-limited and limited conditions respectively. Differences in patterns of $\mathrm{Qp} /$ cell and $\mathrm{Qp} / \mathrm{Q}_{\mathrm{C}}$ along the DR gradient, however, highlight the importance of the reference used (cell or $\mathrm{Q}_{\mathrm{C}}$ ) for quota estimations. Compiling data of ACT03 and TL01 compatible with Droop's theory (obtained at $\left.\mathrm{DR} \geq D R_{3}\right)$, values of the theoretical minimum quota $\mathrm{q}_{\mathrm{o}}\left(16.4 \mathrm{pgP} \cdot \mathrm{cell}^{-1} ; 0.010 \mathrm{pgP} \cdot \mathrm{pgC}^{-1}\right)$ obtained from Droop's model were close to minimal Qp measurements $\left(\mathrm{Qp}_{/ \text {cell-min }}=20.3\right.$ $\left.\mathrm{pgP} \cdot \mathrm{cell}^{-1} ; \mathrm{Qp} / \mathrm{Q}_{\mathrm{C}-\min }=0.010 \mathrm{pgP} \cdot \mathrm{pgC}^{-1}\right)$. Thus, neither ratios between the maximal and minimal Qp measurements $\left(\mathrm{Qp}_{\max } / \mathrm{Q} \mathrm{p}_{\min }\right)$ nor $\mathrm{Qp} \mathrm{p}_{\max } / \mathrm{q}_{\mathrm{o}}$ revealed a particular $\mathrm{P}$ storage capacity of these strains because each ratio (not detailed) was low $(\leq 3.7)$.

A large range of minimal $\left(1.3-83.5 \mathrm{pgP} \cdot \mathrm{cell}^{-1}\right)$ and maximal $\left(1.9-788.7 \mathrm{pgP} \cdot \mathrm{cell}^{-1}\right)$ $\mathrm{Qp}_{\text {/cell }}$ values have been reported for marine dinoflagellates (Sakshaug et al.1984, Ou et al. 2008), suggesting the existence of different P requirements and P-storage capacities between phytoplankton genera. For Alexandrium species, $\mathrm{Qp} /$ /cell-min estimations were obtained for Alexandrium tamarense $\left(23.6 \mathrm{pgP} \cdot \mathrm{cell}^{-1}\right)$ and A. catenella $\left(9.0 \mathrm{pgP} \cdot \mathrm{cell}{ }^{-1}\right)$ by Yamamoto and Tarutani (1999) and Matsuda et al. (2006) respectively, with a high P storage capacity highlighted for A. tamarense from $\mathrm{Qp}_{\max } / \mathrm{q}_{\mathrm{o}}=36$ (cited in Yamamoto and Tarutani 1999). Cellular Qp in these studies, however, were not measured but calculated from the difference of $\mathrm{PO}_{4}{ }^{3-}$ concentration between input and output media, which makes difficult a direct comparison with our $\mathrm{Qp}_{\text {/cell }}$ data. More comparable results for Alexandrium species were obtained by Ou et al. (2008) and Béchemin et al. (1999). Ou et al. (2008) reported similar $\mathrm{Qp}_{/ \text {cell-min }}\left(24.7 \mathrm{pgP} \cdot \mathrm{cell}^{-1}\right)$ but two times higher $\mathrm{Qp} /$ cell-max values for A. catenella, leading to 
$\mathrm{Qp}_{\max } / \mathrm{Qp}_{\min }=7.68$ which also suggests low $\mathrm{P}$ storage capacity of this species. According to Béchemin et al. (1999), A. minutum may present even lower P-storage capacities as they did not observe a trend in $\mathrm{Qp}_{\text {/cell }}$ variations along a $\mathrm{P}$-stress gradient, defined by $\mathrm{N}: \mathrm{P}$ ranging from 16 to 160 , with $\mathrm{Qp}_{/ \mathrm{cell}}$ values oscillating between 8.7 and $14.3 \mathrm{pgP} \cdot \mathrm{cell}^{-1}$. Additional estimations under transient conditions, however, are required for a more ecologically relevant estimation of P-storage capacities of A. catenella cells (Spijkerman and Coesel 1998). Alkaline phosphatase activity. Alkaline phosphatases activity is often used as another P-limitation indicator (Cembella et al. 1984, Dyhrman and Palenik 2003) as it is inducible by low extracellular $\mathrm{PO}_{4}{ }^{3-}$ concentrations for many marine phytoplankton species. However, additional factors may regulate AP synthesis (Hoppe 2003) and, in particular for the Alexandrium genus, APA appeared to be a poor indicator of $\mathrm{PO}_{4}{ }^{3-}$-stress for A. minutum, A. tamarense and A. affine cells (Flynn et al. 1996). Among the potential controlling factors, a regulation by the intracellular P-pool has often been reported, for example by Xu et al. (2006) who noted a delay of several hours in the induction of genes associated with AP synthesis by E. huxleyi after cells transfer in P-depleted conditions.

In the present study, fractionated APA measurements were done to estimate cell bound and dissolved APA. Both AP synthesized by phytoplankton (Huang et al. 2005, Xu et al. 2006) and bacteria (Hoppe 1991) may be released into the water and contribute to the dissolved APA pool. The low levels of dissolved APA measured during our experiments indicate that APA was mainly cell bound in our cultures and that activity from the $>10 \mu \mathrm{m}$ fraction described adequately APA originating from $A$. catenella.

Contrary to the observations of Flynn et al. (1996) on other species of Alexandrium, the regulation of AP synthesis by extracellular $\mathrm{PO}_{4}{ }^{3-}$ concentrations appears to be straightforward in A. catenella cells, defined by a threshold value between $0.4 \mu \mathrm{M}$ and 1.0 $\mu \mathrm{M}$ of $\mathrm{PO}_{4}{ }^{3-}$. Such threshold values have been reported for other marine phytoplankton 
species (Table 2) revealing that this parameter is species specific, with a high inter-Class variability. The $\mathrm{PO}_{4}{ }^{3-}$ concentration threshold observed for $A$. catenella is in accordance with the one characterizing A. tamarense (Oh et al. 2002), while values reported for other toxic dinoflagellates ranged from $0.2 \mu \mathrm{M}$ for Karenia mikimotoi (Yamaguchi et al. 2004) to $3.3 \mu \mathrm{M}$ for Gymnodinium catenatum (Oh et al. 2002). Regulation by the intracellular P-pool did not seem to be as direct as by extracellular $\mathrm{PO}_{4}{ }^{3-}$ concentration. Indeed, the relation between APA and $\mathrm{Qp} /$ cell was not so clear-cut, even though a $\mathrm{Qp} /$ cell value lower than $\sim 40 \mathrm{pgP} \cdot \mathrm{cell}^{-1}$ appears necessary to allow AP synthesis. The control by the intracellular P-pool may take effect principally through the $\mathrm{C}: \mathrm{P}$ stoichiometry because a $\mathrm{Qp} / \mathrm{Q}_{\mathrm{C}}$ value of $0.016 \mathrm{pgP} \cdot \mathrm{pgC}^{-1}$ (atomic $\mathrm{C}: \mathrm{P}=161)$ appeared as a threshold for AP synthesis. Comparing variations of APA and $\mathrm{Qp} / \mathrm{Q}_{\mathrm{C}}$ along the DR gradient, normalized APA per cell increased drastically when $\mathrm{Qp} / \mathrm{Q}_{\mathrm{C}}$ started to decrease ( $D R_{l}$ on Figure 6) but did not vary further under more severe P-stress conditions. Thus, synthesis of AP by A. catenella cells appears to be induced and maximized as soon as P-limitation sets in. According to Ou et al. (2006), this maximization of APA synthesis may also be observed at the population scale. From batch cultures of A. catenella, these authors noted that a change in bulk APA of 0 to $1.42 \mathrm{nmolP} \cdot \mathrm{L}^{-1} \cdot \mathrm{h}^{-1}$ during two consecutive days was associated with a change of enzyme-labeled fluorescent cells from 1.4 $\%$ to $100 \%$, where cells were labeled on their active AP sites located on the cell surface by a fluorescent precipitate.

The characterization of APA in A. catenella cells may be complemented from the analysis of kinetic parameter values. Values obtained for TL01 and ACT03 appeared to be very close. Compiling data of both A. catenella strains, APA was characterized by an affinity constant $\left(\mathrm{K}_{\mathrm{S}}\right)$ of $1.3 \pm 0.7 \mu \mathrm{M}$ and a potential maximal activity value $\left(\mathrm{V}_{\max }\right)$ of $12.5 \pm 2.8$ fmolP.cell ${ }^{-1} \cdot \min ^{-1}$. Ou et al. (2008) determined lower kinetics parameters values for $A$. catenella cells $\left(\mathrm{K}_{\mathrm{S}}=0.55 \mu \mathrm{M}, \mathrm{V}_{\max }=2.88 \mathrm{fmolP} \cdot \mathrm{cell}^{-1} \cdot \mathrm{min}^{-1}\right)$ using another fluorogenic 
400

401

402

403

404

405

406

407

408

409

410

411

412

413

414

415

416

417

418

419

420

421

422

423

substrate, MFP. However, it is problematic to compare between studies when different AP substrates are being used (Dyhrman 2005). Comparing marine phytoplankton studies based on similar APA assays, values obtained for A. catenella reveal that this species shows a major competitive advantage for utilizing the DOP resource at low concentrations (Table 3).

Phosphate uptake characteristics. Metabolic adaptations of A. catenella cells to graded P-limitation in terms of $\mathrm{PO}_{4}{ }^{3-}$ uptake include the control of $\mathrm{Vp}_{\max }$ which was clearly linked with extracellular $\mathrm{PO}_{4}{ }^{3-}$ concentrations and $\mathrm{Qp} / \mathrm{Q}_{\mathrm{C}}$, but no characteristic influence of $\mathrm{Qp} /$ cell on $\mathrm{Vp}_{\max }$ could be identified. Thus, as for $\mathrm{AP}$ regulation, $\mathrm{PO}_{4}{ }^{3-}$ uptake rates appear to be regulated by the intracellular P quota only through an indirect pathway, the P:C stoichiometry of the cell. The exponential decrease in $\mathrm{Vp}_{\max }$ as a function of $\mathrm{Qp} / \mathrm{Q}_{\mathrm{C}}$ reveals that $A$. catenella cells are able to optimize their $\mathrm{PO}_{4}{ }^{3-}$ uptake capacity as the $\mathrm{P}$-deficiency increases. Even if, under P-limitation, the specific APA per cell did not rise with the P-stress, this potential optimization of $\mathrm{PO}_{4}{ }^{3-}$ uptake may also benefit to the DOP utilization as $\mathrm{PO}_{4}{ }^{3-}$ released from APA may be more rapidly taken up. The maximal reached value of $\mathrm{Vp}_{\max }$ was $1.9 \mathrm{fmolP} \cdot \mathrm{cell}^{-1} \cdot \mathrm{min}^{-1}$ (for TL01) corresponding to $0.13 \mathrm{~h}^{-1}$. This value is low compared to the one reported for A. catenella $\left(2.5 \mathrm{~h}^{-1}\right)$ by Ou et al. (2008) and for the other dinoflagellates $A$. tamarense $\left(1.8 \mathrm{~h}^{-1}\right.$, Yamamoto and Tarutani (1999)) and G. catenatum $\left(0.31 \mathrm{~h}^{-1}\right.$, Yamamoto et al. (2004)) or the diatom S. costatum $\left(2.6 \mathrm{~h}^{-1}\right.$, Ou et al. (2008)). Thus, Thau lagoon strains of A. catenella showed relatively poor competitive abilities under high $\mathrm{PO}_{4}{ }^{3-}$ concentrations. Concerning abilities under low concentrations, $\mathrm{K}_{\mathrm{S}}$ measured in this study $(0.01-1.17 \mu \mathrm{M})$ are in accordance with the range $(0.4-1.68 \mu \mathrm{M})$ reported for Alexandrium species by Cembella et al. (1984), Yamamoto and Tarutani (1999) and Frangópulos et al. (2004). Ou et al. (2008), however, characterized a Chinese strain of $A$. catenella by a higher $\mathrm{K}_{\mathrm{S}}$ of $2.28 \mu \mathrm{M}$. Based on the summary of reported $\mathrm{K}_{\mathrm{S}}$ values $(0.01-2.8 \mu \mathrm{M})$ for marine phytoplankton species 
proposed by Yamamoto and Tarutani (1999), $\mathrm{K}_{\mathrm{S}}$ values obtained for Thau lagoon strains of $A$. catenella indicate a more efficient competitor for $\mathrm{PO}_{4}{ }^{3-}$ at low concentrations.

Ecological considerations. The appearance of A. catenella in Thau lagoon (France) waters followed a long term decrease in $\mathrm{PO}_{4}{ }^{3-}$ concentrations (Collos et al. 2009). This suggests that a modification of the bottom-up control of A. catenella bloom development may have occurred. The periodic dominance of this species may be partly explained by its competitive capacities to take up $\mathrm{PO}_{4}{ }^{3-}$ at low concentrations and by its abilities to use DOP resources. Considering A. catenella blooms in spring 2002 and autumn 2003, AP synthesis has been likely to be induced during a large part of blooms durations as $\mathrm{PO}_{4}{ }^{3-}$ concentrations lower than $0.4 \mu \mathrm{M}$ were measured during $80 \%$ and $33 \%$ of the bloom duration in 2002 and 2003, respectively (unpublished data). Under such environmental conditions, A. catenella may have a competitive advantage from DOP use when APA is induced, as the range of in situ DOP concentrations (0.6-1.4 $\mu \mathrm{M}$, Laugier, T.) was low but close to the $\mathrm{K}_{\mathrm{S}}$ of APA (1.3 $\mu \mathrm{M})$. Thus, A. catenella bloom developments in Thau lagoon in 2002 and 2003 may have been sustained by the DOP resource, with a significant part of P-uptake based on APA. A similar assumption was proposed by Ou et al. (2008) for A. catenella developments in Chinese coastal waters.

\section{CONCLUSION}

Shifts in trends of $\mathrm{Qp} / \mathrm{Q}_{\mathrm{C}}, \mathrm{Qp}_{\text {/cell }}$ and cell density variations along the $\mathrm{DR}$ gradient allow the definition of three successive P-stress thresholds for A. catenella cells. For each strain, a slight change in DR values, from $0.3 \mathrm{~d}^{-1}$ to $0.2 \mathrm{~d}^{-1}$ for ACT03 and from $0.4 \mathrm{~d}^{-1}$ to 0.2 $\mathrm{d}^{-1}$ for TL01, was sufficient to induce a shift from P-sufficient conditions to P-starvation. Thus, A. catenella cells show a very high sensitivity to P-stress, with the TL01 strain presenting slightly higher P-requirements than ACT03. APA was a robust indicator of $\mathrm{PO}_{4}{ }^{3-}-$ 
449

450

451

452

453

454

455

456

457

458

459

460

461

462

463

464

465

466

467

468

469

470

471

472

473

limitation for A. catenella cells. Additional in situ measurements have to be performed to assess to what extent DOP utilization may be considered as a key competitive advantage for A. catenella cells in Thau lagoon waters with regards to other controlling factors.

\section{ACKNOWLEDGMENTS}

This study was financed by CNRS (Centre National de la Recherche Scientifique) and Ifremer (Institut Français de Recherche pour l'Exploitation de la Mer) ALTOX program. C.J. was supported by a scholarship from the Région Languedoc-Roussillon and Ifremer.

\section{REFERENCES}

Aminot, A. \& Kérouel, R. 2004 Mesures des concentrations en carbone, azote et phosphore organiques particulaires. In Ifremer [Ed.] Hydrologie des écosystèmes marins. Paramètres et analyses. Ifremer, Plouzané, France, pp. 194-214.

Aminot, A. \& Kérouel, R. 2007. Dosage automatique des nutriments dans les eaux marines: méthodes en flux continu. In Ifremer [Ed.] Méthodes d'analyse en milieu marin. Ifremer, Plouzané, France, pp. 123-131.

Ammerman, J. W. 1993. Microbial cycling of inorganic and organic phosphorus in the water column. In Kemp, P. F., Sherr, B. F., Sherr, E. B. \& Cole, J. J. [Eds.] Handbook of methods in aquatic microbial ecology. Lewis, Boca Raton, pp. 649-60.

Andersen, R. A., Berges, J. A., Harrison, P. J. \& Watanabe, M. M. 2005. Recipes for freshwater and seawater media. In Andersen, R. A. [Ed.] Algal culturing techniques. Elsevier, Amsterdam, pp. 429-538.

Béchemin, C., Grzebyk, D., Hachame, F., Hummert, C. \& Maestrini, S. Y. 1999. Effect of different nitrogen/phosphorus nutrient ratios on the toxin content in Alexandrium minutum. Aquat. Microb. Ecol. 20:157-65. 
474 Cembella, A. D., Antia, N. J. \& Harrison, P. J. 1984. The utilization of inorganic and organic 475 phosphorus compounds as nutrients by eukaryotic microalgae: a multidisciplinary 476 perspective. II. Crit. Rev. Microbiol. 11:13-81.

477 Collos, Y., Bec, B., Jauzein, C., Abadie, E., Laugier, T., Lautier, J., Pastoureaud, A., Souchu, 478 P. \& Vaquer, A. 2009. Oligotrophication and emergence of picocyanobacteria and a toxic 479 dinoflagellate in Thau lagoon, southern France. J. Sea. Res. 61:68-75.

480 Delmas, D., Legrand, C., Bechemin, C. \& Collinot, C. 1994. Exoproteolytic activity 481 determinated by flow injection analysis: its potential importance for bacterial growth in coastal marine ponds. Aquat. Living Resour. 7:17-24.

Droop, M. R. 1968. Vitamin $B_{12}$ and marine ecology. IV. The kinetics of uptake, growth and inhibition in Monochrysis lutheri. J. Mar. Biol. Assoc. U.K. 48:689-733.

Droop, M. R. 1974. The nutrient status of algal cells in continuous culture. J. Mar. Biol. Assoc. U.K. $54: 825-855$.

Dyhrman, S. T. 2005. Ectoenzymes in Prorocentrum minimum. Harmful Algae. 4:619-627. Dyhrman, S. T. \& Palenik, B. 2003. Characterization of ectoenzyme activity and phosphateregulated proteins in the coccolithophorid Emiliana huxleyi. J. Plankton Res. 25:1215-25. Flynn, K., Jones, K. J. \& Flynn, K. J. 1996. Comparisons among species of Alexandrium (Dinophyceae) grown in nitrogen- or phosphorus-limiting batch culture. Mar. Biol. 126:9-18. Frangópulos, M., Guisande, C., deBlas, E. \& Maneiro, I. 2004. Toxin production and competitive abilities under phosphorus limitation of Alexandrium species. Harmful Algae. 3:131-9.

García-Ruiz, R., Hernandez, I., Lucena, J. \& Niell, F. X. 1997. Preliminary studies on the significance of alkaline phosphatase activity in the diatom Phaeodactylum tricornutum Bohlin. Sciantia Marina. 61:517-25. 
Hoppe, H. G. 1983. Significance of exoenzymatic activities in the ecology of brackish water: measurements by means of methylumbelliferyl-substrates. Mar. Ecol. Prog. Ser. 11:299-308. Hoppe, H. G. 1991. Microbial extracellular enzyme activity: a new key parameter in aquatic ecology. In Chrost, R. J. [Ed.] Microbial enzymes in aquatic environments. Springer-Verlag, New York, pp. 60-83.

Hoppe, H. G. 2003. Phosphatase activity in the sea. Hydrobiologia. 493:187-200.

Huang, B. Q., Ou, L. J., Hong, H. S., Luo, H. W. \& Wang, D. Z. 2005. Bioavailability of dissolved organic phosphorus compounds to typical harmful dinoflagellate Prorocentrum donghaiense Lu. Mar. Pol. Bul. 51:838-44.

Karl, D. M. \& Björkman, K. M. 2002. Dynamics of DOP. In Hansell, D. A. \& Carlson, C. A. [Eds.] Biogeochemistry of marine dissolved organic matter. Academic Press, San Diego, CA., USA, pp. 249-366.

Karl, D. M. \& Yanagi, K. 1997. Partial characterization of the dissolved organic phosphorus pool in the oligotrophic North Pacific Ocean. Limnol. Oceanogr. 42:1398-405.

Labry, C., Delmas, D. \& Herbland, A. 2005. Phytoplankton and bacterial alkaline phosphatase activities in relation to phosphate and DOP availability within the Gironde plume waters (Bay of Biscay). J. Exp. Mar. Biol. Ecol. 318:213-25.

La Jeunesse, I. \& Elliott, M. 2004. Anthropogenic regulation of the phosphorus balance in the Thau catchment-coastal lagoon system (Mediterraean Sea, France) over 24 years. Mar. Pol. Bull. 48:679-87.

Le Floc'h, E., Malara, G., \& Sciandra, A. 2002. An automatic device for in vivo absorption spectra acquisition and chlorophyll estimation in phytoplankton cultures. J. App. Phycol. $14: 435-44$ 
521

522

523

524

525

526

527

528

529

530

531

532

533

534

535

536

537

538

539

540

541

542

543

544

545

Lilly, E. L., Kulis, D. M., Gentien, P. \& Anderson, D. M. 2002. Paralytic shellfish poisoning toxins in France linked to a human-introduced strain of Alexandrium catenella from the western Pacific: evidence from DNA and toxin analysis. J. Plankton Res. 24:443-52.

Matsuda, A., Nishijima, T., Fukami, K. \& Adachi, M. 2006. Growth kinetics and paralytic shellfish poisoning toxin production in phosphorus-limited cultures of Alexandrium catenella. Nippon Suisan Gakkaishi. 72:193-200.

McComb, R. B., Bowers Jr, G. N. \& Posen, S. 1979. Alkaline Phosphatase. Plenum Publishing Corp., New York, 986 pp.

Oh, S. J., Yamamoto, T., Kataoka, Y., Matsuda, O., Matsuyama, Y. \& Kotani, Y. 2002. Utilization of dissolved organic phosphorus by the two toxic dinoflagellates, Alexandrium tamarense and Gymnodinium catenatum (Dinophyceae). Fisheries Science. 68:416-24.

Ou, L. J., Huang, B. Q., Lin, L. Z., Hong, H. S., Zhang, F. \& Chen, Z. Z.. 2006. Phosphorus stress of phytoplankton in the Taiwan Strait determined by bulk and single-cell alkaline phosphatase activity assays. Mar. Ecol. Prog. Ser. 327:95-106.

Ou, L., Wang, D., Huang, B., Hong, H., Qi, Y. \& Lu, S. 2008. Comparative study of phosphorus strategies of three typical harmful algae in Chinese coastal waters. J. Plankton Res. 30:1007-17.

Perry, M. J. 1972. Alkaline phosphatase activity in subtropical Central North Pacific waters using a sensitive fluorometric method. Mar. Biol. 15:113-9.

Riegman, R., W. Stolte, A. A. M. Noordeloos, and D. Slezak. 2000. Nutrient uptake, and alkaline phosphate (EC 3:1:3:1) activity of Emiliania huxleyi (Prymnesiophyceae) during growth under N and P limitation in continuous cultures. J. Phycol. 36(1):87-96.

Sakshaug, E., Granéli, E., Elbrächter, M. \& Kayser, H. 1984. Chemical composition and alkaline phosphatase activity of nutrient-saturated and P-deficient cells of four marine dinoflagellates. J. Exp. Mar. Biol. Ecol. 77:241-54. 
546 Sciandra, A. \& Ramani, P. 1994. The steady states of continuous cultures with low rates of

547 medium renewal per cell. J. Exp. Mar. Biol. Ecol. 178:1-15.

548 Shafik, H. M., Herodek, S., Voros, L., Presing, M. \& Kiss, K. T. 1997. Growth of Cyclotella

549 meneghiniana Kutz. I. Effects of temperature, light and low rate of nutrient supply.

$550 \quad$ International J. Limnol. 33:139-47.

551 Shanks, A. L. \& Trent, J. D. 1979. Marine snow - Microscale nutrient patches. Limnol.

552 Oceanogr. 24:850-4.

553 Solórzano, L. \& Sharp, J. H. 1980. Determination of total dissolved phosphorus and

554 particulate phosphorus in natural waters. Limnol. Oceanogr. 25:754-8.

555 Spijkerman, E. \& Coesel, P. F. M. 1998. Different response mechanisms of two planktonic

556 desmid species (chlorophyceae) to a single addition of phosphate. J. Phycol. 34:438-445.

557 Suzumura, M. \& Ingall, E. D. 2004. Distribution and dynamics of various forms of

558 phosphorus in seawater: insights from field observations in the Pacific Ocean and a laboratory

559 experiment. Deep-Sea Research I. 51:1113-30.

560 Thingstad, T. F., Zweifel, U. L. \& Rassoulzadegan, F. 1998. P limitation of heterotrophic

561 bacteria and phytoplankton in the northwest Mediterranean. Limnol. Oceanogr. 43:88-94.

562 Thingstad, T. F., Krom, M. D., Mantoura, R. F. C., Flaten, G. A. F., Groom, S., Herut, B.,

563 Kress, N., Law, C. S., Pasternak, A., Pitta, P., Psarra, S., Rassoulzadegan, F., Tanaka, T.,

564 Tselepides, A., Wassmann, P., Woodward, E. M. S., Riser, C. W., Zodiatis, G. \& Zohary, T.

565 2005. Nature of phosphorus limitation in the ultraoligotrophic eastern Mediterranean. Science.

566 309:1068-71.

567 Tilman, D. \& Kilham, S. S. 1976. Phosphate and silicate growth and uptake kinetics of the

568 diatoms Asterionella formosa and Cyclotella meneghiniana in batch and semicontinuous

569 culture. J. Phycol. 12:375-83. 
570 Vargo, G. A. \& Shanley, E. 1985. Alkaline-phosphatase activity in the red-tide dinoflagellate,

571 Ptychodiscus-brevis. Mar. Ecol. 6:251-64.

572 Vidal, M., Duarte, C. M., Agusti, S., Gasol, J. M. \& Vaque, D. 2003. Alkaline phosphatase

573 activities in the central Atlantic Ocean indicate large areas with phosphorus deficiency. Mar.

574 Ecol. Prog. Ser. 262:43-53.

575 Xu, Y., Wahlund, T. M., Feng, L., Shaked, Y. \& Morel, F. M. M. 2006. A novel alkaline

576 phosphatase in the coccolithophore Emiliania huxleyi (Prymnesiophyceae) and its regulation

577 by phosphorus. J. Phycol. 42:835-44.

578 Yamaguchi, H., Nishijima, T., Nishitani, H., Fukami, K. \& Adachi, M. 2004. Organic

579 phosphorus utilization and alkaline phosphatase production of 3 red tide phytoplankton.

580 Nippon Suisan Gakkaishi. 70:123-30.

581 Yamaguchi, H., Sakou, H., Fukami, K., Adachi, M., Yamaguchi, M. \& Nishijima, T. 2005.

582 Utilization of organic phosphorus and production of alkaline phosphatase by the marine 583 phytoplankton, Heterocapsa circularisquama, Fibrocapsa japonica and Chaetoceros

584 ceratosporum. Plankton Biol. Ecol. 52:67-75.

585 Yamamoto, T. \& Tarutani, K. 1999. Growth and phosphate uptake kinetics of the toxic

586 dinoflagellate Alexandrium tamarense from Hiroshima Bay in the Seto Inland Sea, Japan.

587 Phycol. Res. 47:27-32.

588 Yamamoto, T., Oh, S. J. \& Kataoka, Y. 2004. Growth and uptake kinetics for nitrate, 589 ammonium and phosphate by the toxic dinoflagellate Gymnodinium catenatum isolated from 590 Hiroshima Bay, Japan. Fisheries Science. 70:108-15. 
1 TABLE 1 . Values of kinetic parameters $\left(K_{\mathrm{S}}\right.$ in $\mu \mathrm{M}$ and $V_{\max }$ in fmolP.cell $\left.{ }^{-1} \cdot \mathrm{min}^{-1}\right)$ obtained for

$2 \mathrm{PO}_{4}{ }^{3-}$ uptake rate and APA at different dilution rates $\left(\mathrm{d}^{-1}\right)$. APA results compiled data

3 obtained using uniphasic and biphasic Michaelis-Menten models, with values detailed for

4 each phase in case of biphasic patterns. Both phases of biphasic patterns are denoted as phases

$5 \quad$ I and II and represent data modeling in the low and high substrate concentration ranges

6 respectively. Dashes indicate which values of $K_{\mathrm{S}}(*)$ and $V_{\max }(* *)$ for APA are comparable

7 between uniphasic and biphasic patterns.

\begin{tabular}{|c|c|c|c|c|c|c|}
\hline \multirow{3}{*}{$\begin{array}{c}\text { Kinetic } \\
\text { parameters }\end{array}$} & \multirow[t]{3}{*}{ Strain } & \multirow{3}{*}{$\begin{array}{c}\text { Dilution } \\
\text { rate }\end{array}$} & \multirow{3}{*}{$\begin{array}{l}\mathrm{PO}_{4}^{3-} \\
\text { uptake }\end{array}$} & \multicolumn{3}{|c|}{ APA } \\
\hline & & & & \multirow[t]{2}{*}{ Uniphasic } & \multicolumn{2}{|c|}{ Biphasic } \\
\hline & & & & & Phase I & Phase II \\
\hline \multirow[t]{6}{*}{$K_{\mathrm{S}}$} & TL01 & 0.15 & 1.17 & $1.22 *$ & - & - \\
\hline & & 0.2 & 0.44 & - & $0.82 *$ & 11.64 \\
\hline & & 0.3 & 0.01 & - & $0.29 *$ & 26.58 \\
\hline & АCT03 & 0.1 & 0.14 & $1.79 *$ & - & - \\
\hline & & 0.15 & 0.03 & - & $1.47 *$ & 27.55 \\
\hline & & 0.2 & 0.04 & $2.33 *$ & - & - \\
\hline \multirow[t]{5}{*}{$V_{\max }$} & TL01 & 0.15 & 1.97 & $11.8 * *$ & - & - \\
\hline & & 0.2 & 0.77 & - & 6.61 & $9.64 * *$ \\
\hline & & 0.3 & 0.49 & - & 5.24 & $8.89 * *$ \\
\hline & АCT03 & 0.1 & 1.75 & $14.29 * *$ & - & - \\
\hline & & 0.15 & 0.75 & - & 9.04 & $15.26^{* *}$ \\
\hline
\end{tabular}


0.2

0.48

$14.84^{* *}$

8 
TABLE 2. Values of $\mathrm{PO}_{4}{ }^{3-}$ concentration threshold (in $\mu \mathrm{M}$ ) reported to induce AP synthesis for marine phytoplankton species.

\begin{tabular}{|c|c|c|c|}
\hline Classes & Species & $\begin{array}{c}\mathrm{PO}_{4}^{3-} \text { concentration } \\
\text { threshold }\end{array}$ & Reference \\
\hline
\end{tabular}

Dinophyceae

Alexandrium catenella

Alexandrium tamarense

Gymnodinium catenatum

Karenia mikimotoi

Ptychodiscus brevis

Bacillariophyceae

$\begin{array}{ll}0.4-1 & \text { Present study } \\ 0.43 & \text { Oh et al. (2002) } \\ 3.3 & \text { Oh et al. (2002) } \\ 0.2 & \text { Yamaguchi et al. (2004) } \\ <0.5 & \text { Vargo and Shanley (1985) }\end{array}$

Garcia-Ruiz et al. (1997)

Skeletonema costatum

0.25
Yamaguchi et al. (2004) 
Prymnesiophyceae

Emiliana huxleyi

0.25

Dyhrman and Palenik (2003)

Phaeocystis sp.

0.5

van Boekel and Veldhuis (1990) 
TABLE 3. Comparison of kinetic parameter values $\left(\mathrm{K}_{\mathrm{S}}\right.$ in $\mu \mathrm{M}$ and $\mathrm{V}_{\max }$ in fmolP.cell $\left.{ }^{-1} \cdot \mathrm{min}^{-1}\right)$ reported for APA between A. catenella and other marine phytoplankton species. Compilation limited to previous works where the fluorogenic substrates MUF-P or MFP were used.

\begin{tabular}{cccccc}
\hline \hline Classes & Species & Substrate & $\mathrm{K}_{\mathrm{S}}$ & $\mathrm{V}_{\max }$ & Reference \\
\hline Dinophyceae & Heterocapsa circularisquama & MUF-P & & 3.44 & Yamaguchi et al. (2005) \\
& Prorocentrum donghaiense & MFP & 0.25 & 0.09 & Ou et al. (2008) \\
& Alexandrium catenella & MFP & 0.55 & 2.88 & Ou et al. (2008) \\
& Alexandrium catenella & MUF-P & 1.32 & 12.45 & Present study
\end{tabular}

Bacillariophyceae

$\begin{array}{lcccc}\text { Phaeodactylum tricornutum } & \text { MUF-P } & 3.1 & 186 & \text { Garcia-Ruiz et al. (1997) } \\ \begin{array}{l}\text { Chaetoceros ceratosporum } \\ \text { Skeletonema costatum }\end{array} & \text { MUF-P } & & 1.04 & \text { Yamaguchi et al. (2005) }\end{array}$


Prymnesiophyceae

Emiliana huxleyi

MFP

1.9

3.17

Riegman et al. (2000)

Emiliana huxleyi

MUF-P

2.2

5100

Dyhrman and Palenik (2003) 
Figure legends

Figure 1. Residual phosphate concentrations in semi-continuous cultures of Alexandrium catenella as a function of dilution rate (DR) for both TL01 and ACT03 strains (a), A. catenella cell concentrations (Cell $\mathrm{nb}$ ) and cell distributions in chains of one (x1), two (x2) or four cells (x4) along the same DR gradient for TL01 strain (b) and ACT03 strain (c). Data correspond to means between replicate cultures at equilibrium and standard deviations are indicated for phosphate and cell concentrations.

Figure 2. Phosphorus content per cell of Alexandrium catenella (a) and phosphorus content per cell carbon (b) for both TL01 and ACT03 strains in semi-continuous cultures as a function of dilution rate (DR). Data correspond to averages of values obtained on days 1, 2 and 3 after equilibrium.

Figure 3. Maximal phosphate uptake rates per cell of $A$. catenella for both TL01 and ACT03 strains in semi-continuous cultures, expressed as a function of (a) the dilution rate (DR), (b) the residual phosphate concentration in culture medium and (c) the phosphorus content per cell carbon. Histogram data correspond to averages of values obtained on days 1, 2 and 3 after equilibrium.

Figure 4. Maximal alkaline phosphatase activity per cell of $A$. catenella for both TL01 and ACT03 strains in semi-continuous cultures, expressed as a function of (a) the dilution rate (DR), (b) the residual phosphate concentration in culture medium, (c) the phosphorus content per cell carbon and (d) the phosphorus content per cell of $A$. catenella. Histogram data correspond to averages of values obtained on days 1, 2 and 3 after equilibrium.

Figure 5. Alkaline phosphatase activity per cell of $A$. catenella as a function of methyl-umbelliferyl phosphate (MUF-P) concentration for TL01 strain at DR $=0.3 \mathrm{~d}^{-1}$ (a) and ACT03 strain at DR $=0.15 \mathrm{~d}^{-}$ ${ }^{1}$ (b). Modeled curves correspond to biphasic kinetics based on the Michaelis-Menten model and are denoted as phases I and II for data modeling in the low and high substrate concentration ranges respectively. 
Figure 6. Schematic representation of the different nutrient states of $A$. catenella assessed from trends in cell density (solid line), phosphorus content per cell (dashed line) and phosphorus content per cell carbon (dotted line) as a function of dilution rate (DR). Shifts in trends allowed the definition of three critical $\mathrm{DR}$ values $\left(\mathrm{DR}_{1}, \mathrm{DR}_{2}\right.$ and $\left.\mathrm{DR}_{3}\right)$ representing graded P-stress conditions. 
a)

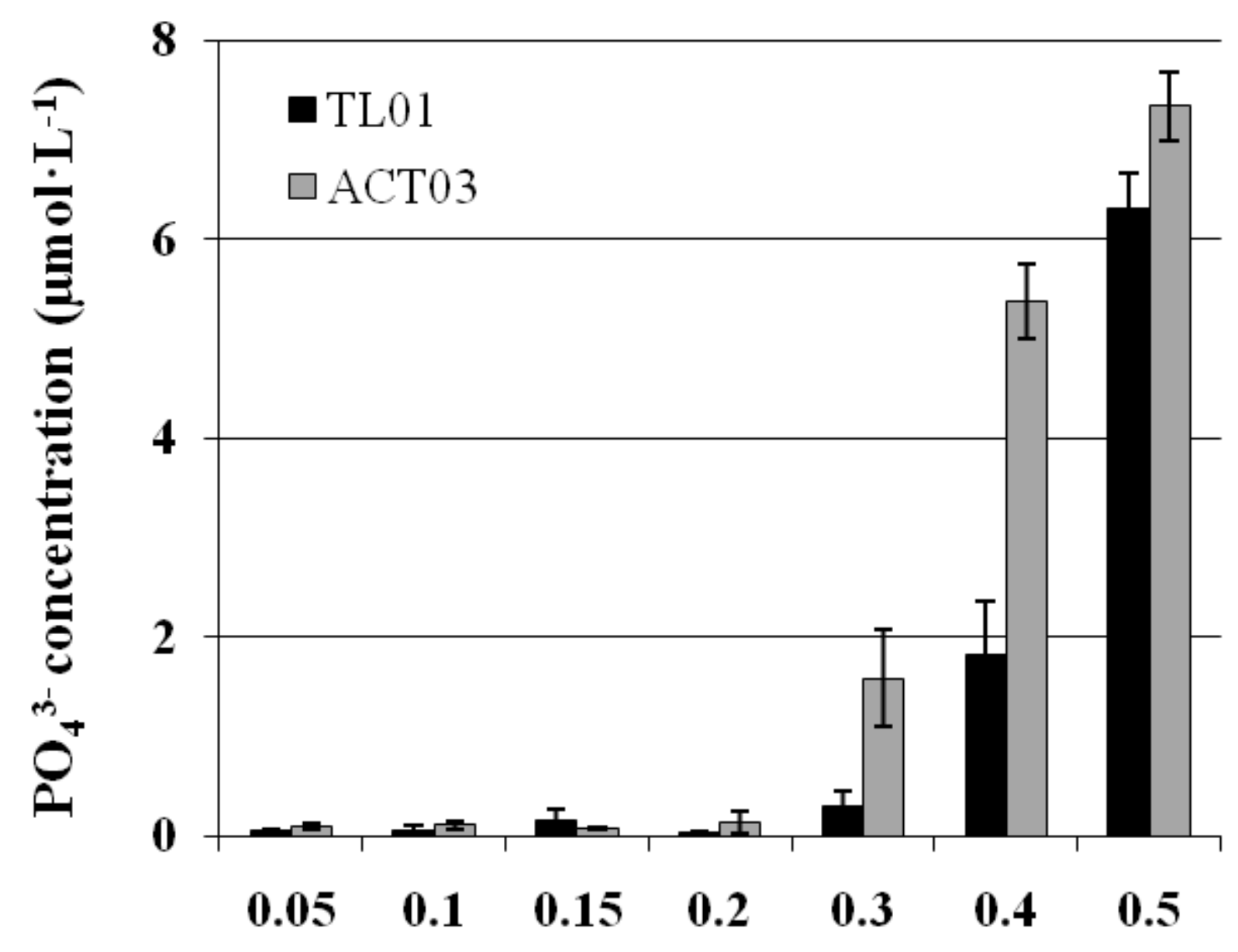

b)

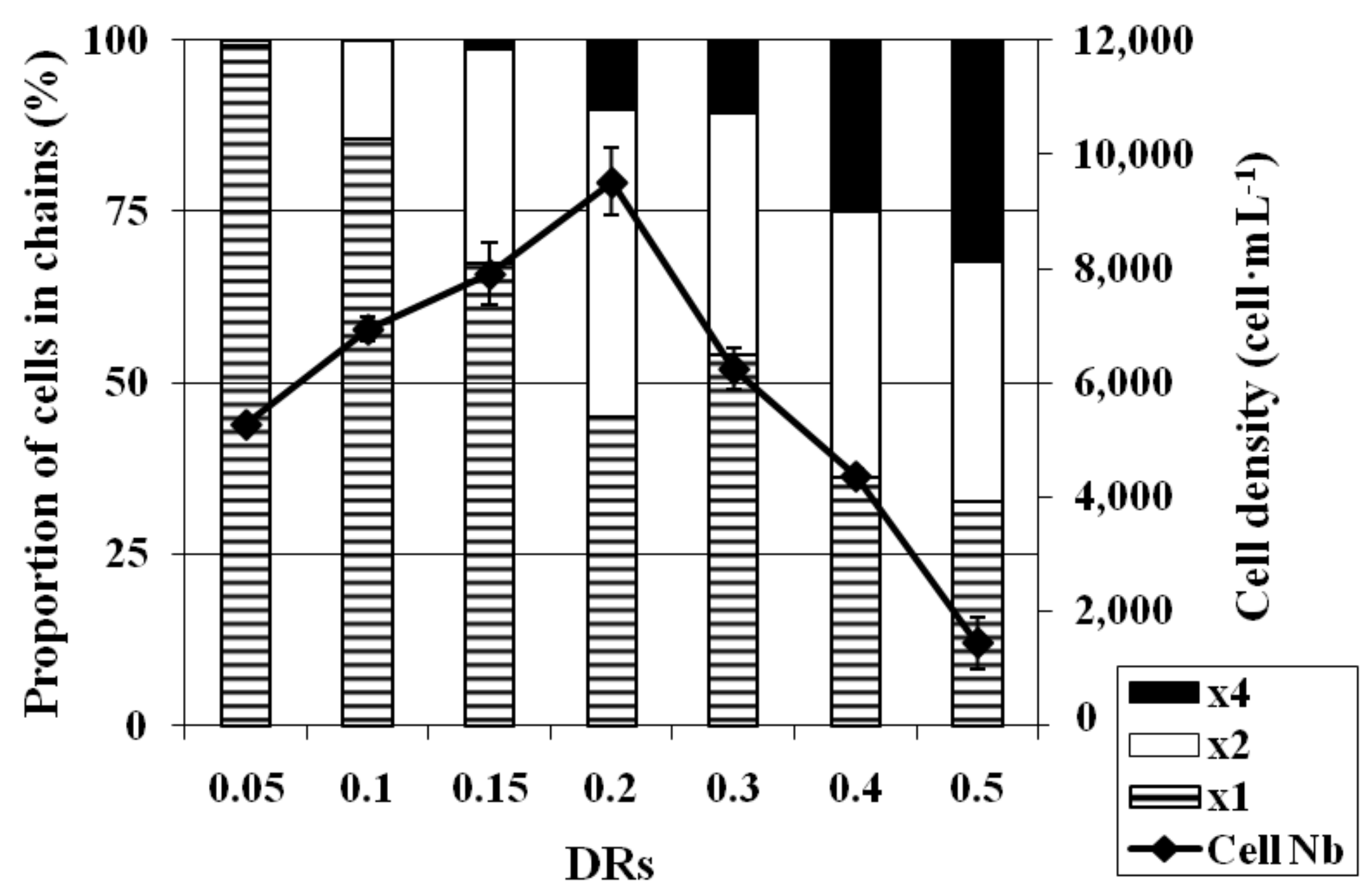

c)

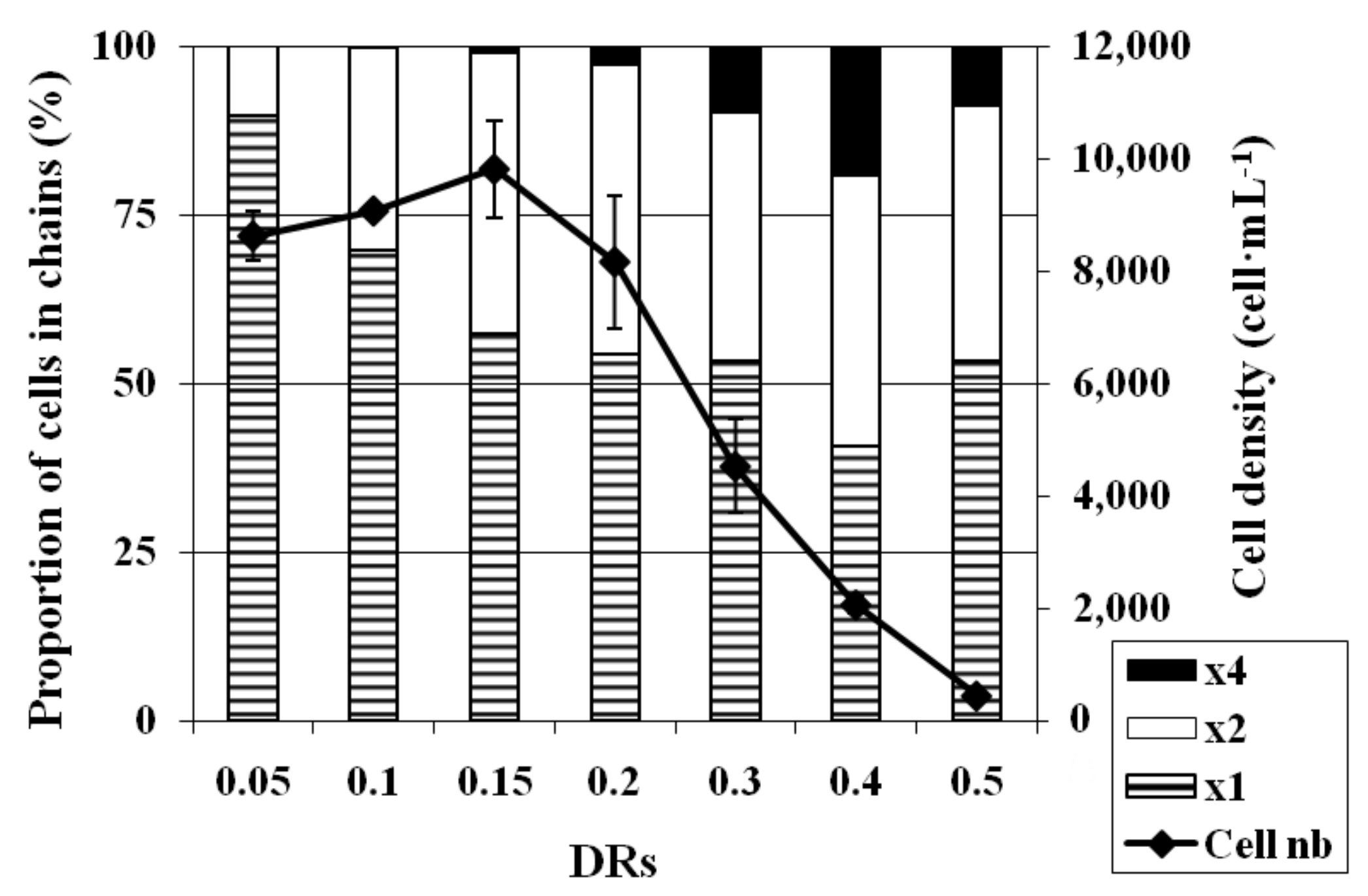


a)

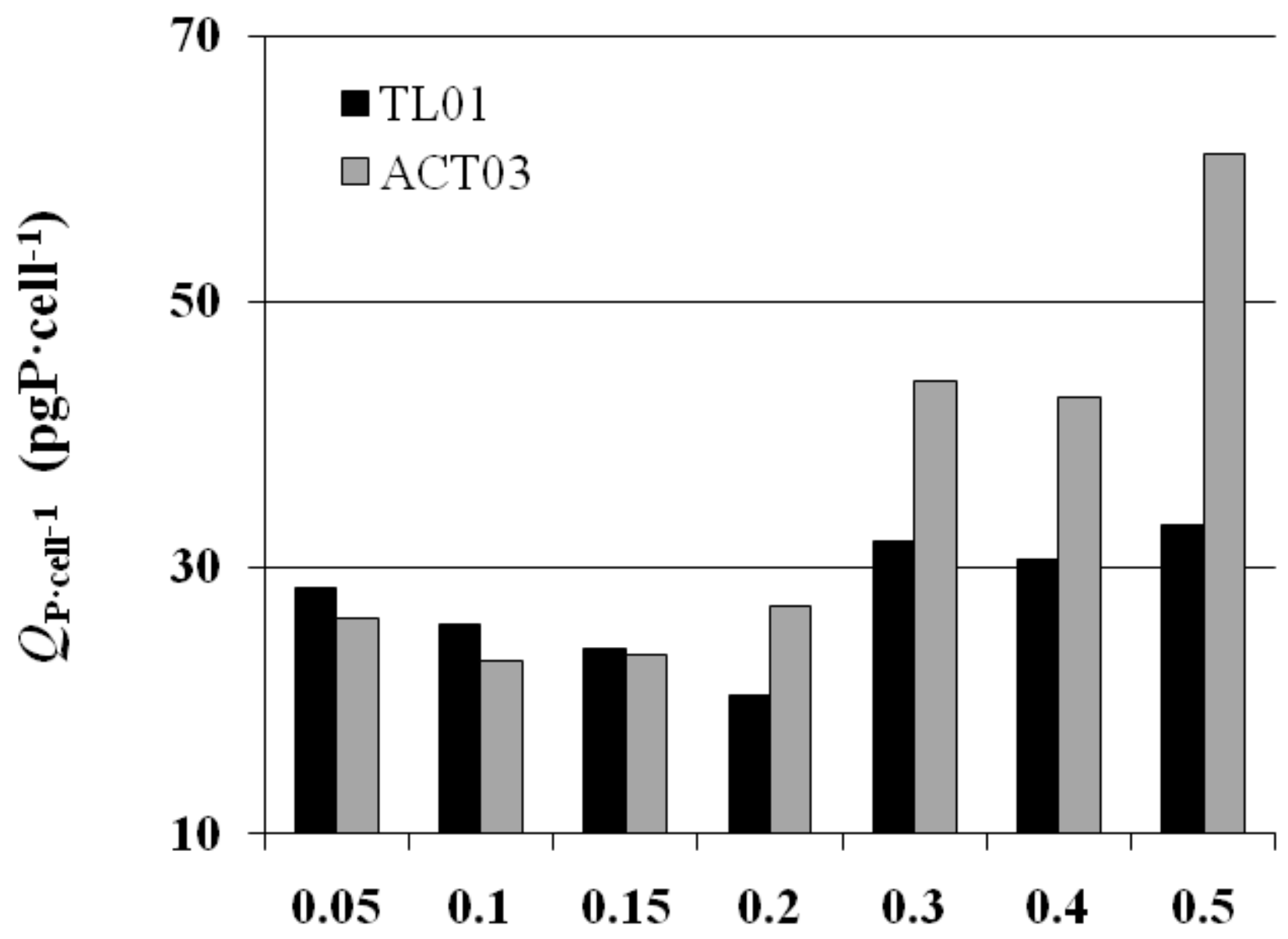

b)

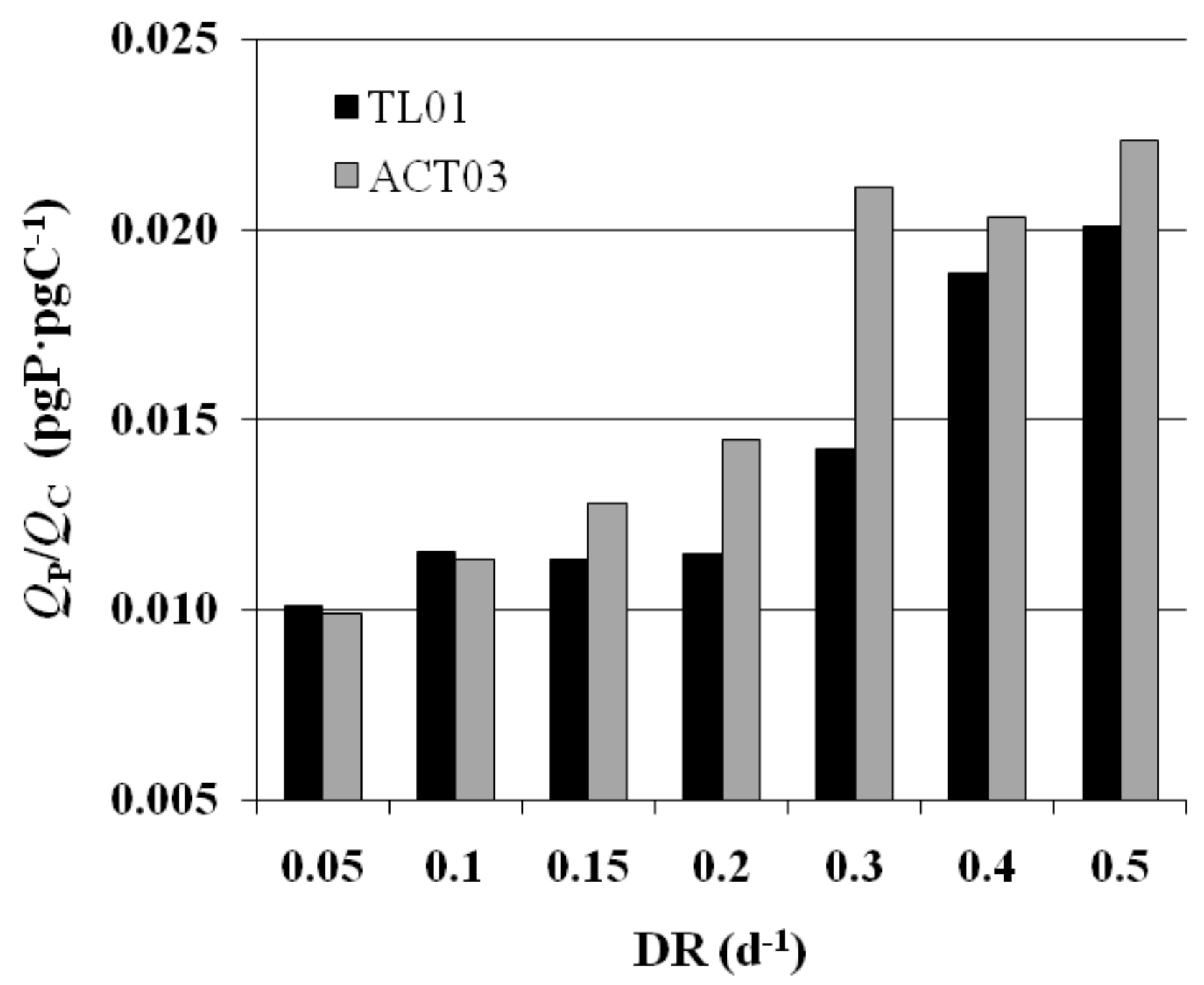


a)

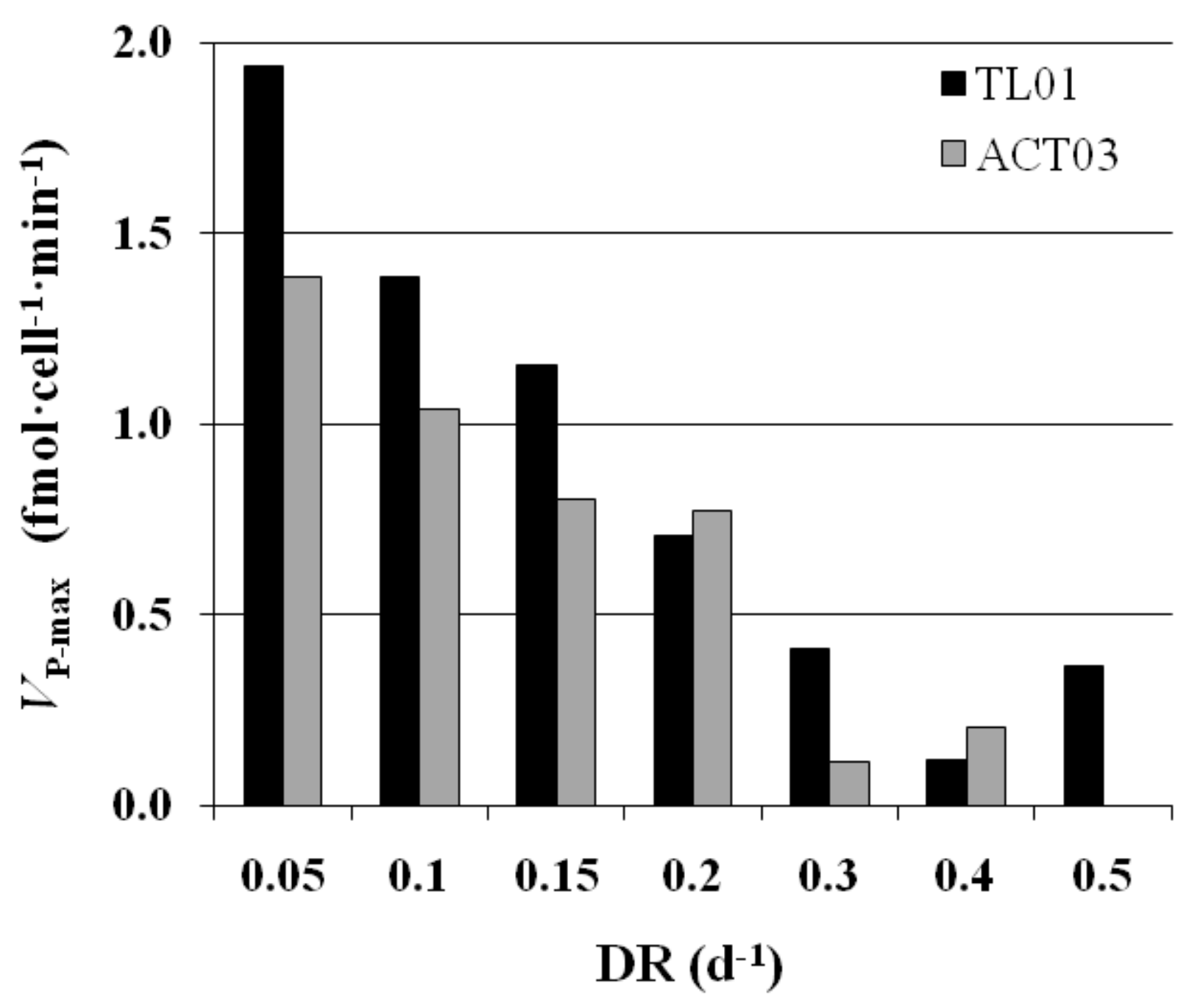

b)

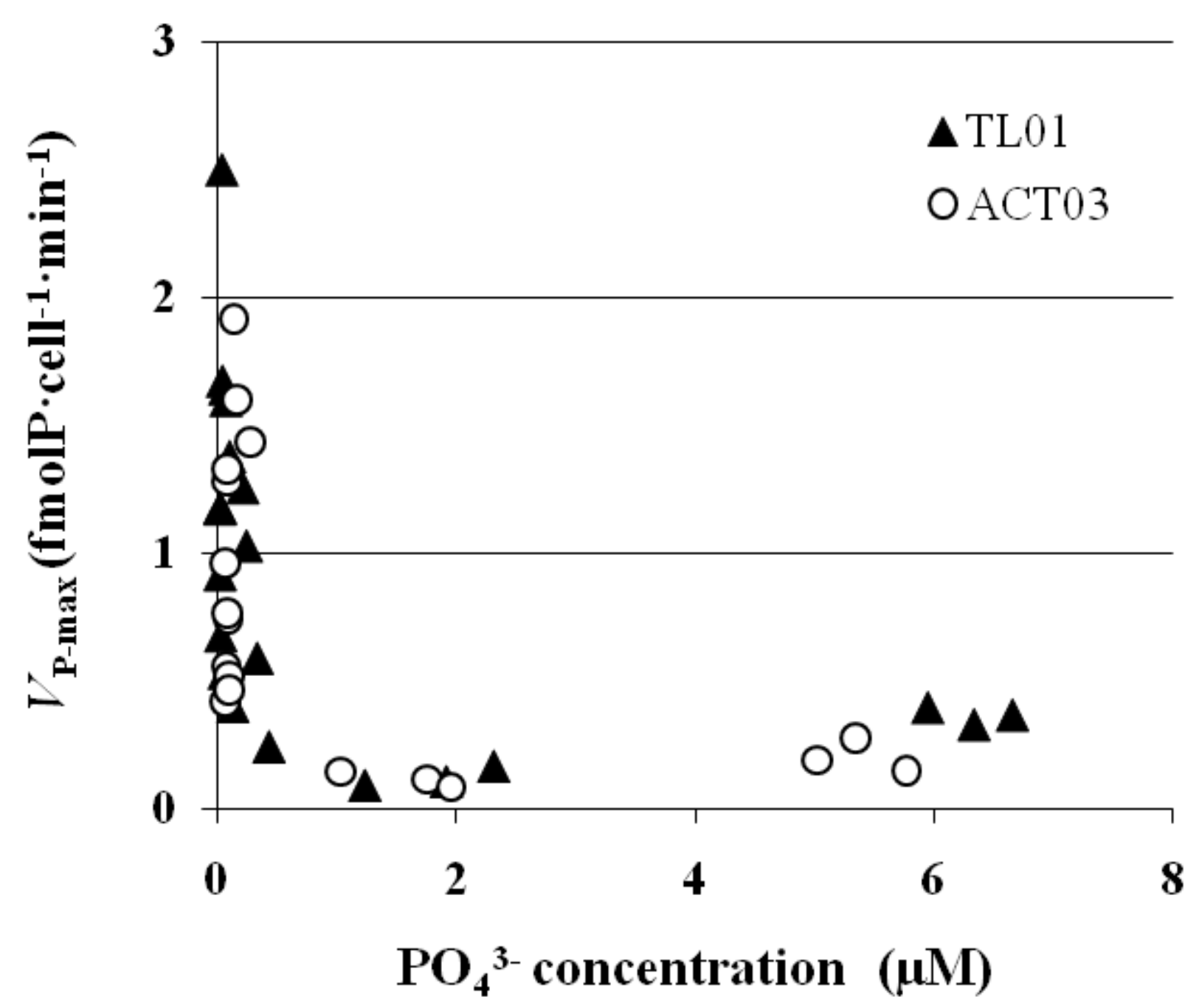

c)

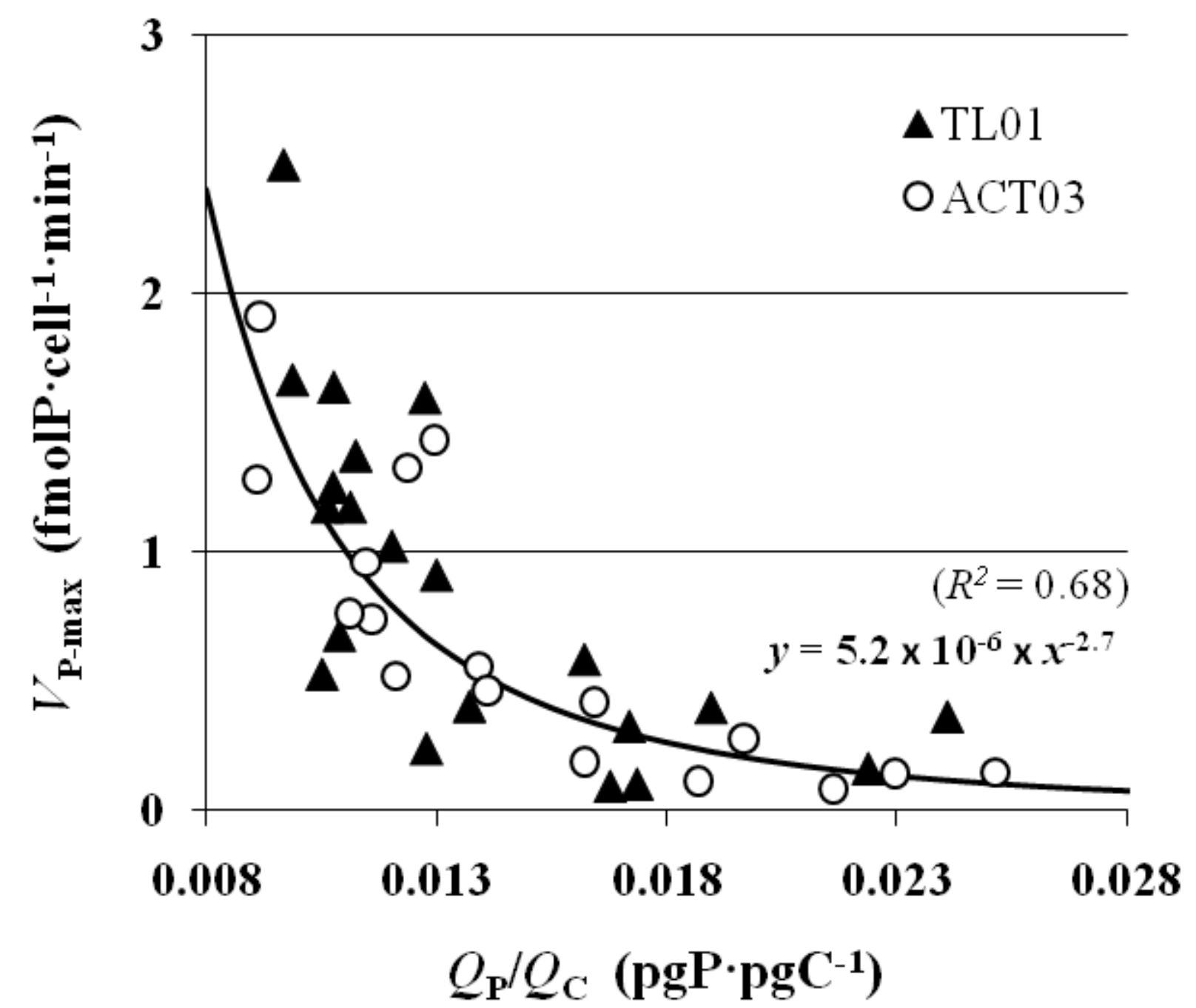


a)

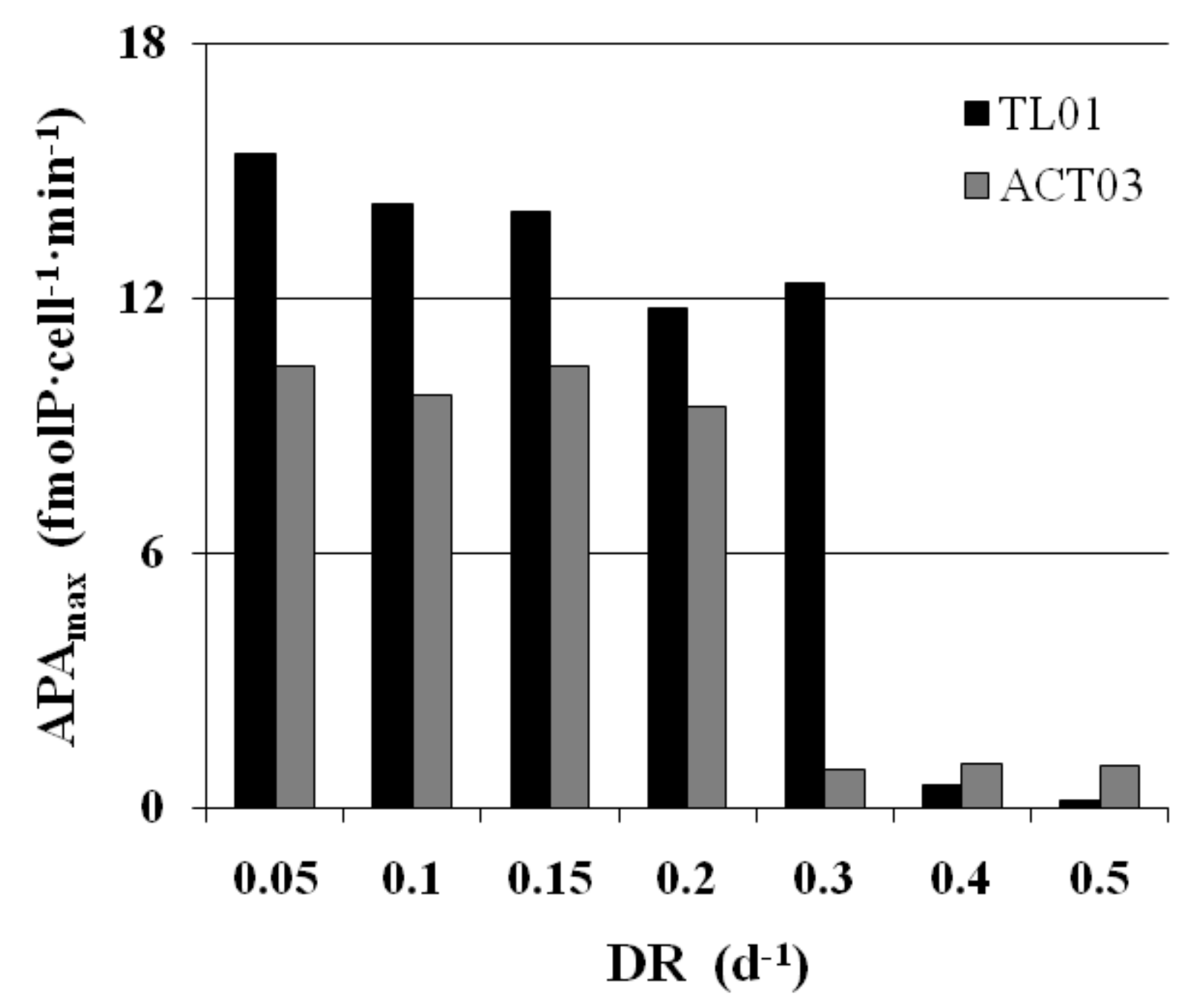

b)

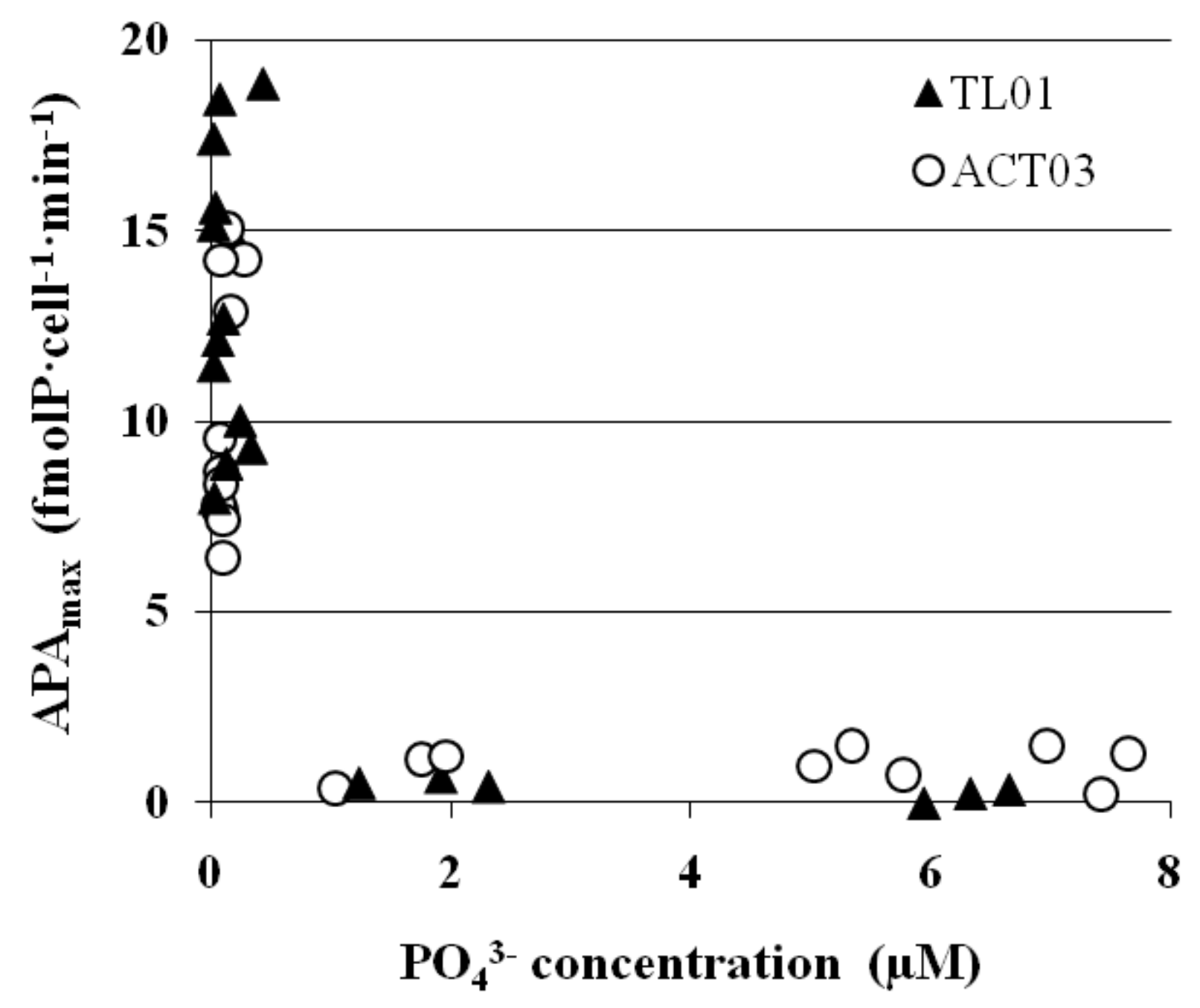

c)

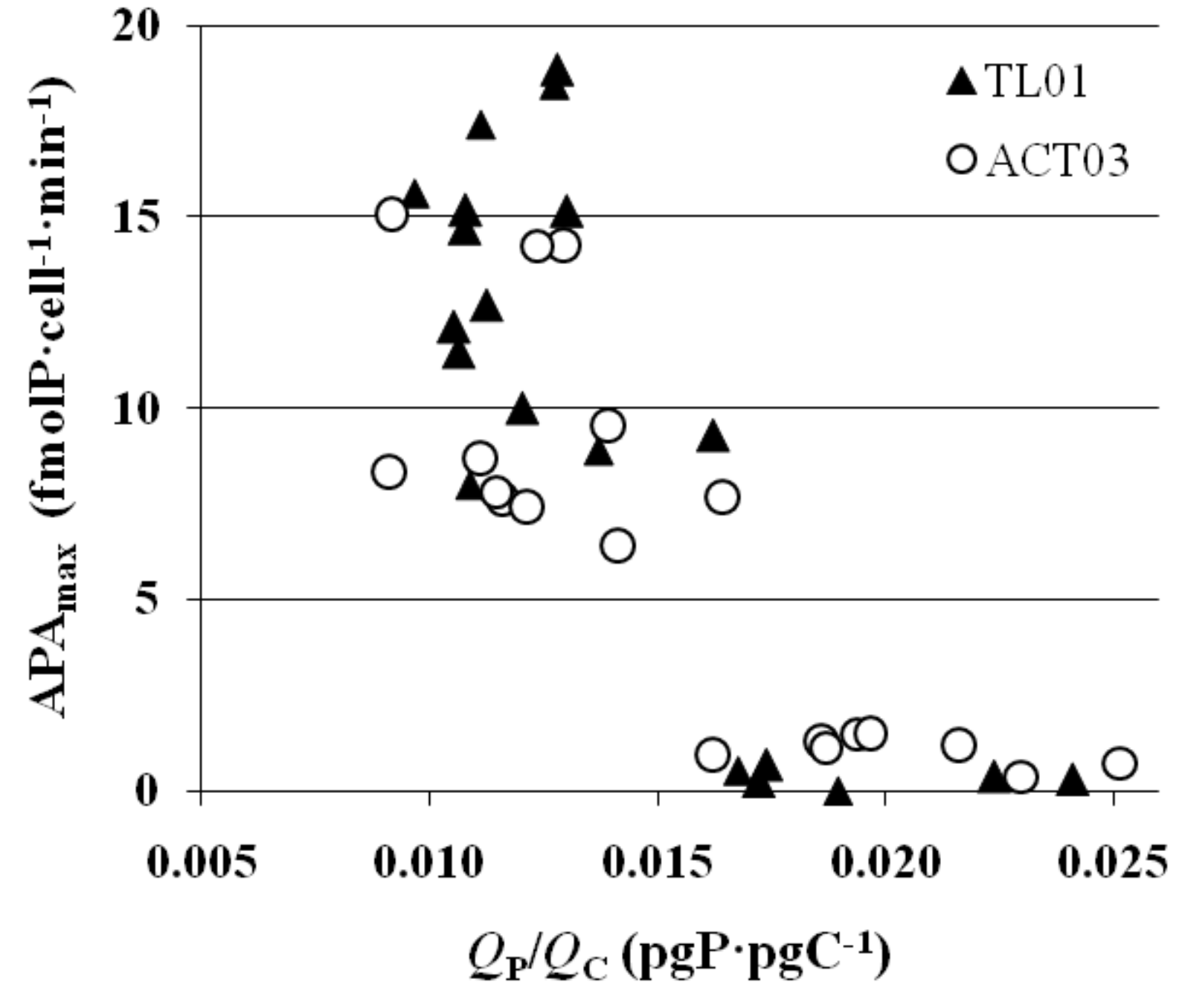

d)

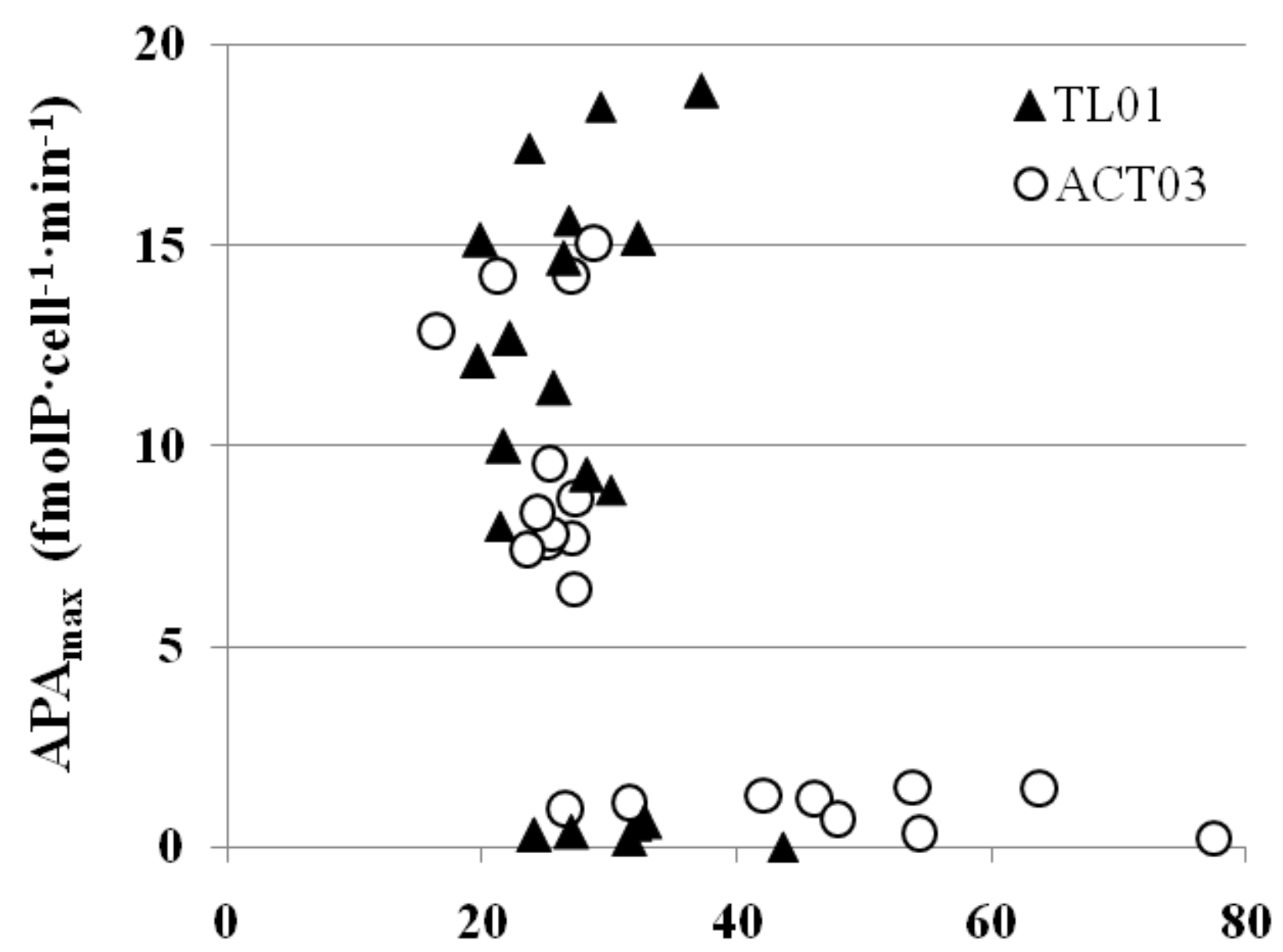

$Q_{\mathbf{P} \cdot \text { cell }^{-1}}\left(\mathbf{p g P} \cdot\right.$ cell $\left.^{-1}\right)$ 
a)

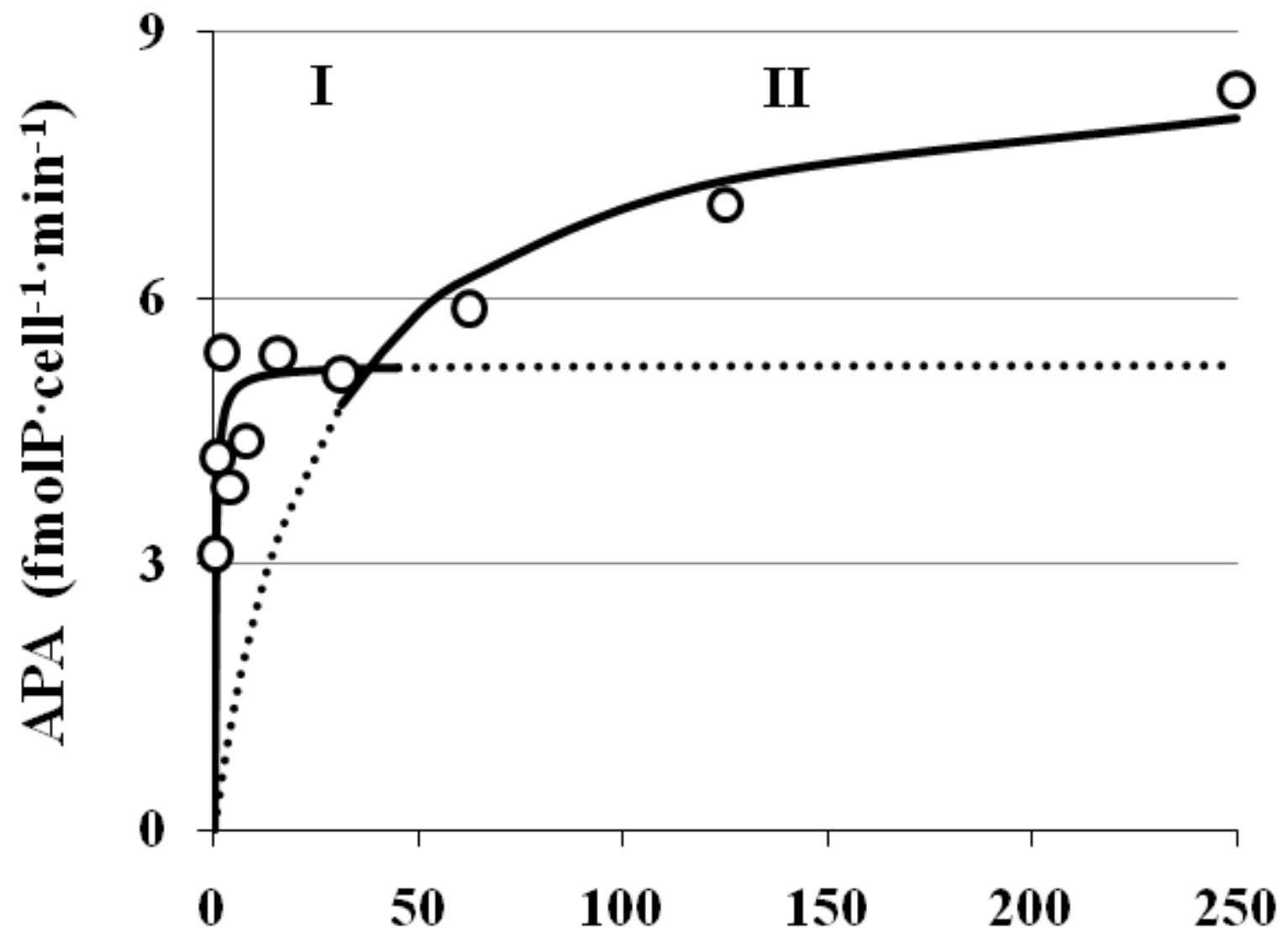

b)

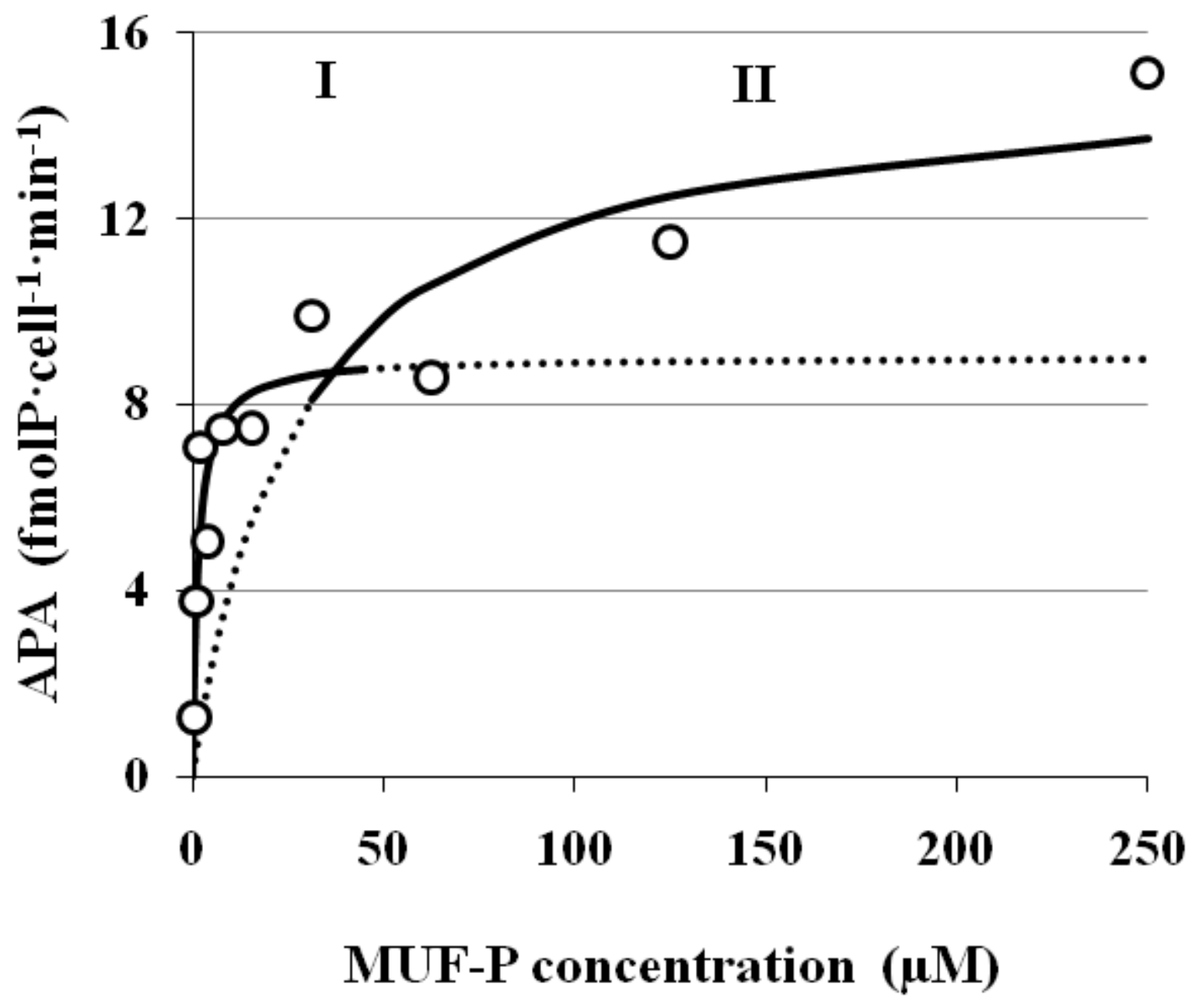


— Cell density

Parameter value

- $Q_{\mathrm{P} \cdot \text { cell }^{-1}}$

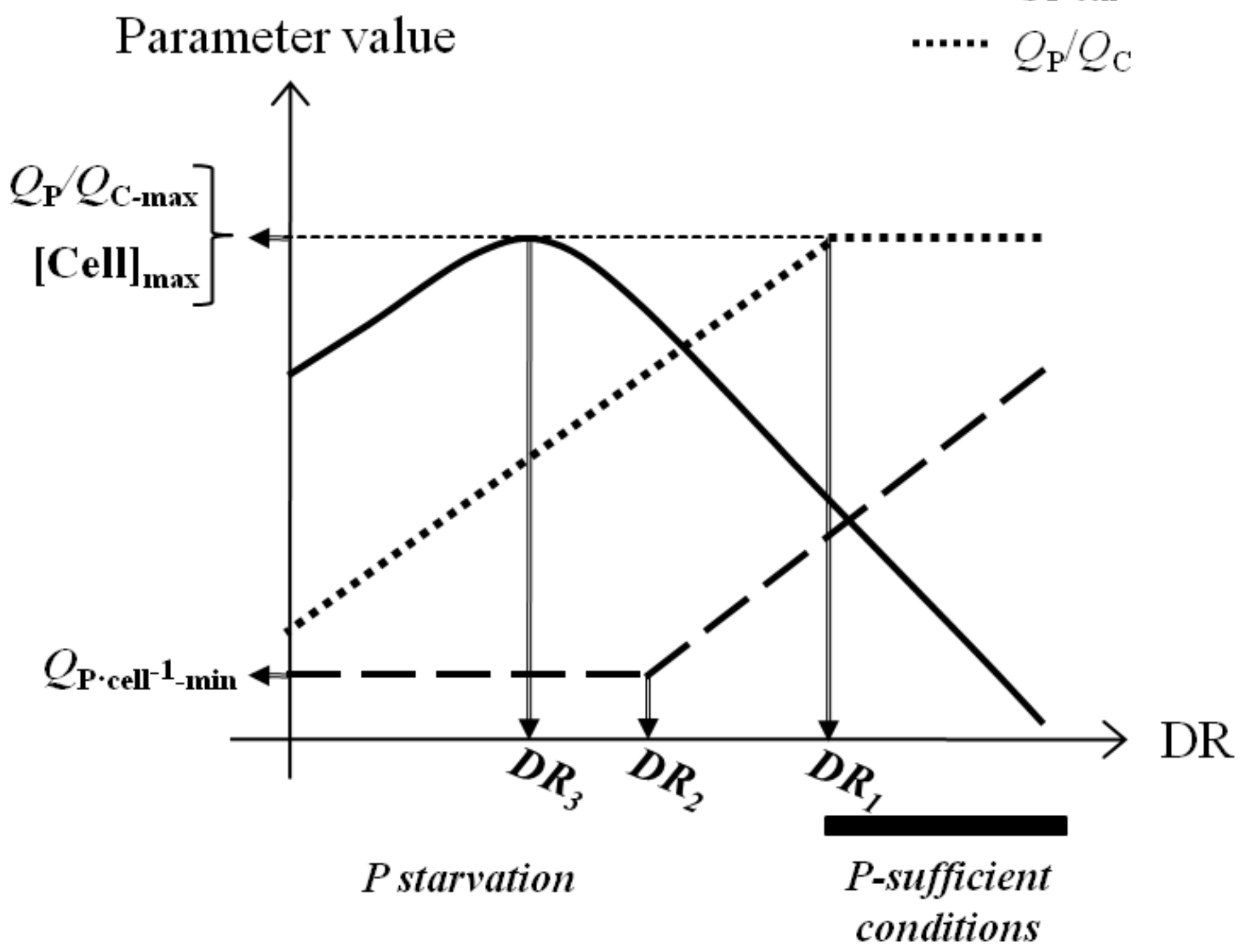

